\title{
O PROBLEMA DO ACASO E A CONSTITUIÇÃO DE PRÁTICAS SEGURADORAS NA HISTÓRIA***
}

\author{
Rafael Mora Camolez \\ Antonio Miguel
}

\begin{abstract}
Resumo
Neste capítulo, é nosso propósito investigar e esclarecer modos como o problema de se evitar riscos a empreendimentos humanos - gerados por eventos aleatórios que se manifestam em diferentes campos de atividade humana, tais como: o do comércio, o da navegação marítima, o da agricultura, o do controle de doenças e epidemias, entre outros teria motivado a emergência e constituição históricas de práticas seguradoras de bens diversos. Procuramos também esclarecer como o problema da evitação dessa variedade de riscos casuais com os quais as práticas seguradoras tiveram que lidar, teria levado ao surgimento de um duplo movimento de controle normativo de tais práticas: um movimento de natureza lógico-normativa que se caracteriza pelo esforço e empenho humanos de se tornar cada vez mais preciso, rigoroso e inequivoco o controle sobre os eventos aleatórios geradores de sinistros; e um movimento de natureza jurídico-normativa que se caracteriza pelo esforço e empenho humanos de se tornar cada vez mais adequadas e justas as leis que regulam os diferentes conflitos que se manifestam nos acordos que humanos estabelecem entre si para se viabilizar a realização de práticas seguradoras de bens diversos contra riscos diversos. O primeiro movimento produziu normatizações científicas e matemáticas que levaram à produção de teorias de probabilidade baseadas em diferentes modos de significação, definição e controle de fenômenos ditos aleatórios ou casuais, que foram posteriormente aplicados como base para os cálculos dos prêmios de diferentes modalidades de seguros. Já o segundo movimento produziu um conjunto de textos legais reguladores de contratos financeiros estabelecidos entre as partes envolvidas nos emprendimentos de risco. A título de ilustração, esclarecemos, particularmente, através de um estudo de caso, o modo como tais teorias orientam atualmente, ainda que apenas parcialmente, a prática de seguros de veículos automotivos.
\end{abstract}

Palavras-chave: práticas seguradoras; campos de atividade humana; eventos aleatórios; história; seguros de veículos automotivos.

\section{Introdução}

A narrativa historiográfica que, neste capítulo, fazemos acerca da emergência de práticas seguradoras de bens diversos contra riscos diversos que se manifestam em diferentes campos de atividade humana vai na contra-mão das histórias evolutivas e progressivistas das

\footnotetext{
* DOI - 10.29388/978-65-86678-51-2-0-f.691-732

** Este texto foi produzido com base no relatório de pesquisa de iniciação científica intitulado Atividades financeiras: um estudo dos cálculos de empreendimentos de risco, desenvolvida por Rafael Mora Camolez, no período de agosto de 2017 a julho de 2018, sob a orientação do professor Antonio Miguel. Registramos aqui os nossos sinceros agradecimentos ao engenheiro naval Cláudio Décourt - que também participa da publicação deste e-book com dois excelentes capítulos - pela leitura e comentários precisos e pertinentes feitos ao texto deste capítulo, que muito contribuíram para a sua revisão.
} 
ciências que veem a normatização lógico-matemática do problema do acaso, isto é, dos modos humanos de se lidar com fenômenos considerados aleatórios - e, por extensão, o advento de teorias de probabilidades e a constituição da Estatística como um campo autônomo de investigação - como o limite comum, abstrato, universal e necessário para o qual deveria tender a multiplicidade diversa - ou a diversidade múltipla - de experiências humanas com fenômenos considerados aleatórios, randômicos, caóticos, casuais, imprevisíveis. Ao contrário, é nosso propósito argumentar em favor do ponto de vista de que desde o surgimento das primeiras comunidades humanas constituidas em e constituintes de diferentes campos de atividade humana - como os do comércio, da navegação marítima, da agricultura, da pecuária, da astronomia, da metereologia, das religiões, da política, da guerra, da jurispruência etc. -, experiências foram realizadas e práticas de controle normativo de fenômenos aleatórios foram inventadas, reiteradamente praticadas e aperfeiçoadas, mesmo na ausência de quaisquer conceitos de probabilidade ou de quaisquer teorizações lógiconormativas acerca de fenômenos considerados aleatórios. É nosso propósito mostrar também que, mesmo na atualidade, em que dispomos de ferramentas conceituais e metodológicas da Estatística e de uma Ciência Atuarial constituída como campo de profissionalização, a multiplicidade de práticas seguradoras - do mesmo modo que para nossos antepassados - continuam tendo que constituir, caso a caso, as suas gramáticas praxiológicas singulares a fim de contemplarem as especificidades de seus propósitos que variam em função da diversidade de bens a serem assegurados, da legislação específica que regulamenta, caso a caso, a multiplicidade de práticas seguradoras que se constituem visando contemplar tais propósitos e de outras inúmeras variáveis que acabam se manifestando imprevisivelmente. Nesse sentido, a nossa narrativa historiográfica se constitui a partir da perspectiva de que as práticas de seguros de bens diversos - e, inclusive, das próprias vidas humanas vistas como um bem - se constituíram historicamente como respostas vitais semelhantes a problemas diversos de prevenção de riscos que se manifestaram - e continuam se manifestando - a diversos empreendimentos vitais de organização da vida humana em diferentes campos de atividade ou formas de vida.

\section{A longevidade de práticas seguradoras em campos de atividade humana}

Os registros mais antigos que remetem práticas seguradoras de bens diversos contra riscos diversos, acham-se descritas no Código de Hamurabi (HAMURABI, c. 1800 a.C.), no

\footnotetext{
1 "Hamurabi foi o sexto rei sumério durante período controverso (1792-1750 ou 1730-1685 a.C.) e nascido em Babel, Khammu-rabi (pronúncia em babilônio) foi fundador do $1^{\circ}$ Império Babilônico, unificando amplamente o mundo mesopotâmico, unindo os semitas e os sumérios e levando a Babilônia (correspondente ao atual Iraque) ao máximo esplendor”. Informação acessível em:

(https://www.portalsaofrancisco.com.br/historia-geral/codigo-de-hamurabi). O professor Simões de Paula assim caracteriza Hamurabi e seu Código de leis: "Hamurabi, conquistador ilustre, é principalmente um legislador. Fez gravar o seu Código num betilo de diorito com os seus 282 artigos, "[...] decretos de equidade", que o deus solar Shamash lhe ditou, do seu celestial trono, ao mesmo tempo que lhe entregava o cetro e o anel — símbolos do poder. Assim, a lei real é também uma lei divina, é a própria palavra de Deus. Pela primeira vez, temos no Oriente Próximo um conjunto coerente e harmonioso de leis e prescrições que regulamentam a vida social, política e econômica de um povo, acompanhado duma grande massa de contratos, extratos de contabilidade, cartas etc. Esse Código é a consequência lógica da necessidade que teve Hamurabi de unificar o mais possível os costumes e os usos tradicionais do seu vasto império, de população heterogênea, composta de semitas em geral, elamitas, sumerianos, subarianos, gutis, amorritas, cassitas etc. Hamurabi não fez distinção alguma entre esses diversos elementos étnicos: legislou para uma sociedade nivelada e unificou as diversas línguas, pois o Código foi escrito em acadiano e como o Código de Napoleão mais tarde, foi ao mesmo tempo um monumento jurídico e um monumento literário” (SIMÕES DE PAULA, 1963, p. 260).
} 
qual são dedicadas algumas cláusulas a atividades similares à bodemeria - uma prática cultural de financiamento de viagens marítimas que isentava os proprietários de navios do pagamento dos valores financiados, caso acidentes viessem a ocorrer ao longo do percurso (BERNSTEIN, 1997). Por outro lado, caso o navio retornasse sem danos, o valor do empréstimo contraído deveria ser totalmente pago, acrescido, porém, de uma parcela proporcional ao lucro obtido por seu proprietário nas transações comerciais realizadas. Uma vez que o reembolso do empréstimo concedido pelo agente financiador ao proprietário do navio dependia do navio concluir com êxito a viagem, a prática da bodemeria era, a rigor, bem mais uma prática de transferência de risco do proprietário do navio ao agente financeiro da viagem do que uma prática de seguro contra sinistros, bastante comum nos nossos dias, em que se paga antecipadamente um prêmio por um bem assegurado e recebe-se um benefício, caso venha a ocorrer um evento de sinistro em relação a esse bem. $\mathrm{Na}$ prática de bodemeria, o proprietário do navio recebe um empréstimo antecipadamente, e só o paga com um prêmio, se um evento de sinistro não ocorrer.

Dentre as cláusulas do Código, não há citações específicas acerca da prática de bodemeria; algumas delas, porém, fazem referência a práticas de seguros no campo agrícola de atividade humana. Tal é o caso da cláusula 48, que garantia a agricultores o direito de não pagamento de juros sobre dívidas contraídas, caso as colheitas, devido a intempéries naturais, se mostrassem desvantajosas em relação aos valores investidos:

$48^{\circ}$ - Se alguém tiver um débito de empréstimo e uma tempestade prostrar os grãos ou a colheita for ruim ou os grãos não crescerem por falta d'água, naquele ano a pessoa não precisa dar ao seu credor dinheiro algum, devendo ele lavar sua tábua de débito na água e não pagar aluguel naquele ano² (HAMURABI, c.1800 a.C., cláusula 48).

Outras práticas preventivas de riscos eram realizadas entre os povos antigos que habitaram o vale da Mesopotâmia, de acordo com as quais dívidas anteriormente contraídas por soldados que viessem a morrer em batalhas não precisariam ser pagas por suas famílias. De acordo com Guimarães (2004), vigorava também, entre comunidades pastoris e de navegadores marítimos da antiga Babilônia, práticas preventivas de riscos baseadas, respectivamente, na compensação de perdas individuais de animais ou embarcações, mediante a assunção e distribuição coletivas de eventuais prejuízos, perdas e danos:

Sentindo as dificuldades e os perigos da travessia [do deserto], como a morte ou o desaparecimento de animais, os cameleiros estabeleceram um acordo: cada membro que perdia um camelo tinha a garantia de receber um outro animal pago pelos demais cameleiros. Da mesma forma, o Código de Hamurabi também promovia, na época, a criação de uma associação que se encarregava de fornecer um novo barco aos comerciantes que o perdessem por causa das tempestades (GUIMARÃES, 2004, p. 6).

$\mathrm{Na}$ Antiguidade, “mútuos" era o nome que se dava a sociedades sem fins lucrativos que reuniam indivíduos com o propósito de cobrir as despesas funerárias de seus associados. Segundo Guimarães (2004), práticas de mutualização - na atualidade, um equivalente a práticas de seguro funerário - foram realizadas na Grécia antiga. Práticas análogas de seguro funerário, denominadas "collegia" (GUIMARÃES, 2004) foram também realizadas no Império

${ }^{2}$ Disponível em: (https://www.portalsaofrancisco.com.br/historia-geral/codigo-de-hamurabi). 
Romano. Por sua vez, segundo Cavicchini (2008), teriam sido práticas de seguro de saúde realizadas entre os gregos antigos as precursoras de práticas de mutualização.

De acordo com Bernstein (1997), a realização de práticas cooperativas de constituição de fundos de reembolso devido a sinistros diversos pode ser acusada na Antiguidade. Como exemplo, ele cita a prática cooperativa criada por mercadores para reembolso de seus sócios por mercadorias perdidas em tempestades ou acidentes de navio.

Práticas cooperativas de constituição de fundos de reembolso devido a sinistros diversos eram também denominadas guildas profissionais, uma vez que visavam proteger, amparar e prestar assistência a integrantes de diferentes comunidades de prática comerciantes, artesãos, navegantes etc. - em casos de acidentes de qualquer natureza de que viessem a ser vítimas no exercício de suas atividades profissionais. Segundo Le Goff,

[...] as guildas são grupos criados por acordo, consentimento e contrato; são associações livres. Consequentemente, elas concluem acordos (convenientiae) e dotam-se de um estatuto. O consentimento e o contrato repousam num juramento mútuo promissivo, ou seja, que envolve comportamentos e ações futuros. Esse juramento faz das guildas associações juramentadas - coniurationes, para retomar o vocabulário das fontes medievais -, mas elas não agradam o poder estabelecido, que se empenha em proibi-las. [...] A constituição de uma guilda tem por objetivo o auxílio mútuo em caso de indigência, incêndio e naufrágio. Trata-se, então, de um sistema de socorro mútuo, destinado a remediar todas as situações de angústia, oferecer uma proteção recíproca e uma assistência social em sentido amplo. Estas compreendem elementos imanente e profanos, mas também elementos transcendentes e religiosos, sempre presentes. As guildas se constituem e continuam a existir para assegurar auxílio mútuo coletivo numa situação de desordem (LE GOFF, 2017, p. 547-548).

Por sua vez, Bernstein destaca o fato de que "[...] as guildas profissionais da Grécia e de Roma mantinham cooperativas cujos membros contribuiam para um fundo que amparava uma familia, caso seu chefe morresse prematuramente" (BERNSTEIN, 1997, p. 92. Acrescenta ainda que práticas semelhantes a essas, nomeadas sociedades beneficentes, foram também realizadas no Lloyd's, no século XVII e que, no século XX, nos EUA, tais sociedades podem ser vistas como precursoras de práticas de seguro industrial, atuando principalmente nas despesas funerárias das famílias de trabalhadores do setor industrial (BERNSTEIN, 1997, p. 95).

Há registros de que, no Império Romano, era realizada uma prática denominada Lex Rhodia de Iactu - ou Jactu. Em casos em que se configurasse o perigo de naufrágios de embarcações, tal prática consistia na permissão de se lançar ao mar as mercadorias que estavam sendo por elas transportadas, dividindo-se proporcionalmente o prejuízo entre os proprietários das mercadorias e os proprietários dos navios. Cavicchini (2008) afirma que, ainda hoje, tal prática - com algumas modificações, mas mantendo o mesmo princípio - é comumente realizada sob o nome de avaria grossa.

Conforme Guimarães (2004), os romanos, no tempo de Júlio César (100 a.C. - 44 a.C.), formaram sociedades com o propósito de se protegerem de prejuízos advindos de chuvas, pragas ou morte. O Imperador Cláudio tomou para si a responsabilidade por perdas de cereais devido a mau tempo, oferecendo uma espécie de seguro gratuito para mercadores e agricultores, a fim de se alavancar o comércio.

A queda do Império Romano do Ocidente arrefeceu as práticas comerciais. No campo comercial, a valorização de práticas seguradoras estava diretamente associada à necessidade 
de diminuição de riscos de produção ou transporte de mercadorias. O arrefecimento das práticas comerciais acabou também promovendo uma desvalorização das demais práticas de seguridade na Europa Ocidental. Entretanto, ao longo de toda a Idade Média, práticas comerciais, náuticas, astronômicas e religiosas - e, com elas, práticas seguradoras e preventivas de riscos - tiveram continuidade entre diferentes povos orientais, entre eles, os hindus que, em seus contatos, desde a Antiguidade, com os povos babilônios que habitaram o vale da Mesopotâmia continuaram a praticar a bodemeria, conforme ficou registrado no Maanava-dharma-shaastra - Leis de Manu - e em outros registros ainda mais antigos que datam de cerca de 600 a.C.

As Leis de Manu são um texto sânscrito da religião hinduísta que apresenta as doutrinas ditadas pelo sábio Manu. Dado que os textos hinduístas não eram datados, alguns historiadores acreditam que o texto das Leis de Manu teria sido escrito durante o reinado do rei hinduísta Púsiamitra Shunga que viveu por volta do século III a.C. Trata-se de um texto composto por 12 capítulos que apresenta as regras de conduta que deveriam ser seguidas pelos indivíduos e pela sociedade. Nele, a referência à prática da bodemeria é feita no capítulo que discorre sobre as leis e costumes relativos aos direitos de propriedade e de herança, o que sugere que a Lei Falcidiana do direito romano poderia ter se inspirado em práticas seguradoras e preventivas de riscos que já vinham sendo praticadas por outros povos, em épocas ainda mais remotas e em outros campos de atividade humana que não o da navegação marítima.

Além disso, o fato de tanto entre hindus quanto entre romanos as referências à prática da bodemeria - à qual, inicialmente, nos referimos como uma prática que havia se constituído exclusivamente com base em necessidades preventivas provenientes do campo nas navegações marítimas - virem associadas a práticas de divisão de heranças e, portanto, aos campos normativos de atividade jurídica ou ético-religiosa, levanta a questão acerca da procedência da prática da bodemeria: se teria sido a necessidade de se precaver contra sinistros que ocorriam no campo de atividade náutica ou a necessidade de se resolver conflitos familiares relativos a divisão de heranças que teria inicialmente pressionado os campos de atividade jurídica e religiosa a estabelecerem critérios reguladores das práticas seguradoras e preventivas de riscos. Em outras palavras, trata-se de saber se práticas seguradoras de bens diversos e preventivas de sinistros provocados por eventos casuais de naturezas diversas teriam se constituído, inicialmente, sob a pressão do campo da navegação marítima e, tendo lá demonstrado a sua eficácia na 'luta contra o mau acaso', teriam sido apropriadas e adaptadas para se precaver contra sinistros aleatórios observados em outros campos de atividade humana, ou se outro campo de atividade humana - que não o da navegação marítima - teria inicialmente se imposto como modelar para os demais. Uma terceira alternativa poderia também ter ocorrido, qual seja, a de que cada campo de atividade em que se manifestou o problema de se precaver contra 0 man acaso teria constituído práticas singulares em função da singularidade de manifestação de eventos casuais em seus domínios.

Jogos imagético-alegóricos de linguagem realizados no campo de atividade artística, dos quais participam deidades mitológicas, gregas ou romanas, vistas como detentoras do poder de controlar o bom on o man acaso, isto é, os diferentes eventos casuais que interferem positiva ou negativamente nas vidas e nos empreendimentos humanos, embora não possam ser aqui

${ }^{3}$ Fonte: (https://es.wikipedia.org/wiki/Leyes_de_Manu). 
tomados como argumentos historiográficos em favor de quaisquer dessas alternativas, podem ser aqui citados como rastros remissivos a práticas outrora realizadas em reforço à nossa conjectura de que, desde tempos bastante remotos, práticas seguradoras teriam sido inventadas e, de fato, praticadas em diferentes campos de atividade humana. Algumas dessas deidades são, por exemplo: as diversas versões da deusa romana da Fortuna, todas elas deidades femininas relacionadas com o acaso, a boa ou má sorte, o destino, a imprevisibilidade, o momento oportuno, a predição, a esperança, as quais, por sua vez, remetem a deusas gregas mais antigas tais como Tique ou Tyche, Ceres e Ops.

O politeísmo antigo não produziu apenas uma variedade de deuses, em função de diferentes desígios humanos, unicamente no interior do campo de atividade religiosa propriamente dita, mas também, várias formas de um mesmo deus - bem como formas variadas de se representá-lo e variedade de templos para se venerá-los - voltadas a cumprir propósitos semelhantes em diferentes campos de atividade humana. É este, por exemplo, o caso da deusa Fortuna, que assumia funções e sobrenomes diversos em função dos diferentes tipos de desígnios individuais, comunitários ou sociopolíticos de que se suponha ter ela o poder de efetivar: desde prognosticar os destinos de vidas pessoais a envolverem-se com determinadas atividades de risco - tais como maternidade, casamento, comércios, guerras etc. , ou os destinos de determinadas atividades comunitárias - tais como o êxito das viagens na atividade comunitária náutica, o êxito e os lucros na atividade intercomunitária comercial, o êxito das colheitas na atividade agrícola etc. -, até o de prognosticar o destino coletivo da atuação de governantes de cidades-estados e de impérios, de políticas estatais etc.

Nesse sentido, podemos rastrear muitos jogos artístico-visuais de linguagem encenando diversamente a deusa romana da Fortuna em conexão a diferentes campos de atividade humana. Em seguida, apresentamos alguns desses jogos.

Nas quatro imagens que se seguem, a deusa da Fortuna aparece empunhando, em uma das mãos, uma cornucópia, isto é, um vaso em forma de chifre repleto de frutas e flores. $\mathrm{Na}$ outra mão, ela segura um ramo de cereais, na maioria das vezes, ramos dourados de trigo, simbolizando a fertilidade, a riqueza e a abundância, tanto na vida pessoal quanto nas atividade do comércio e da agricultura. 


\section{Imagem $1^{4}$}

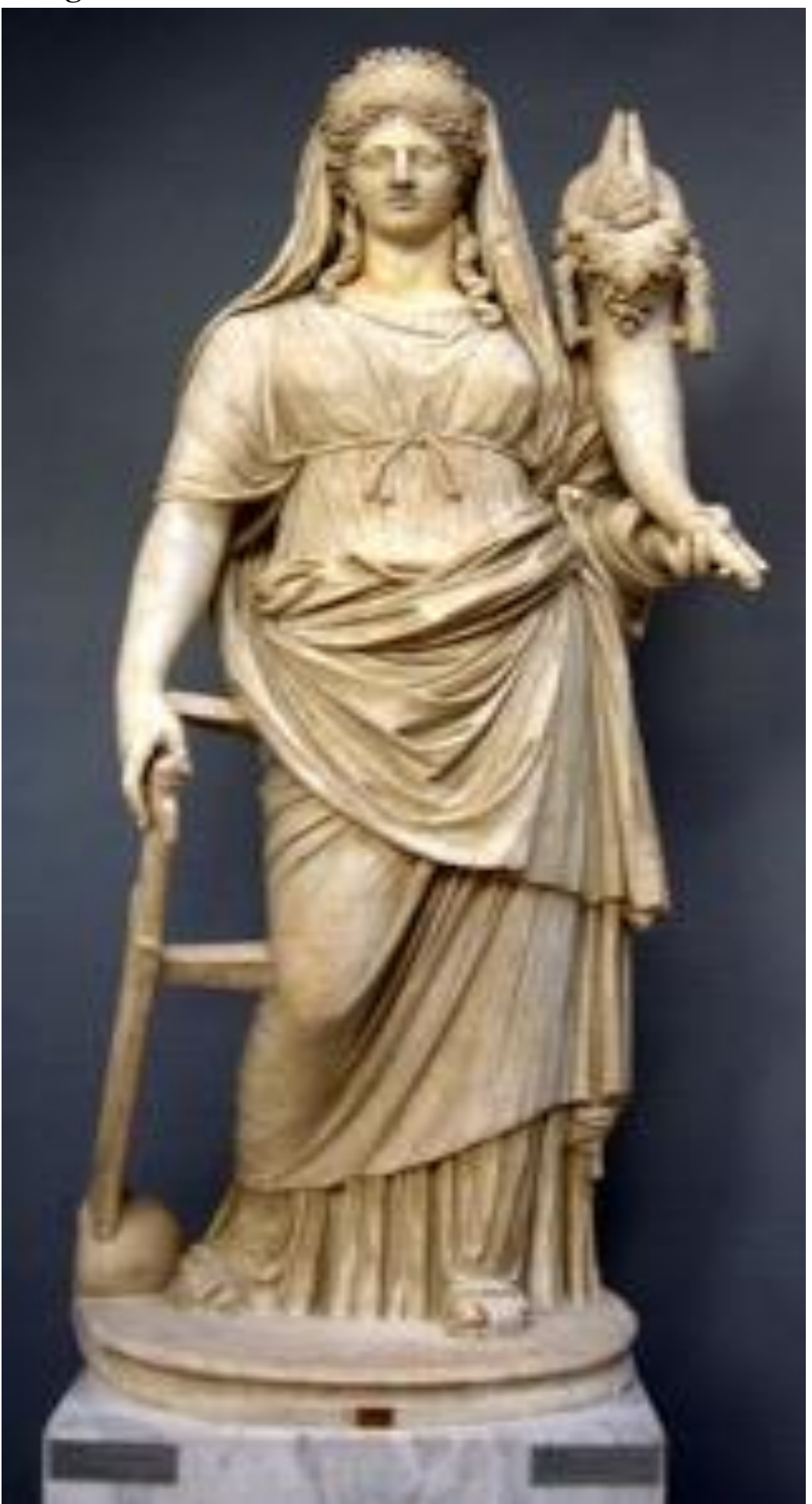

${ }^{4}$ Foto da deusa da Fortuna com cornucópia extraída do site seguinte, acessado em 20 de agosto de 2020: (https://vignette.wikia.nocookie.net/olympians/images/f/f8/Fortuna-

Prosper.JPG/revision/latest?cb=20120305054729). 


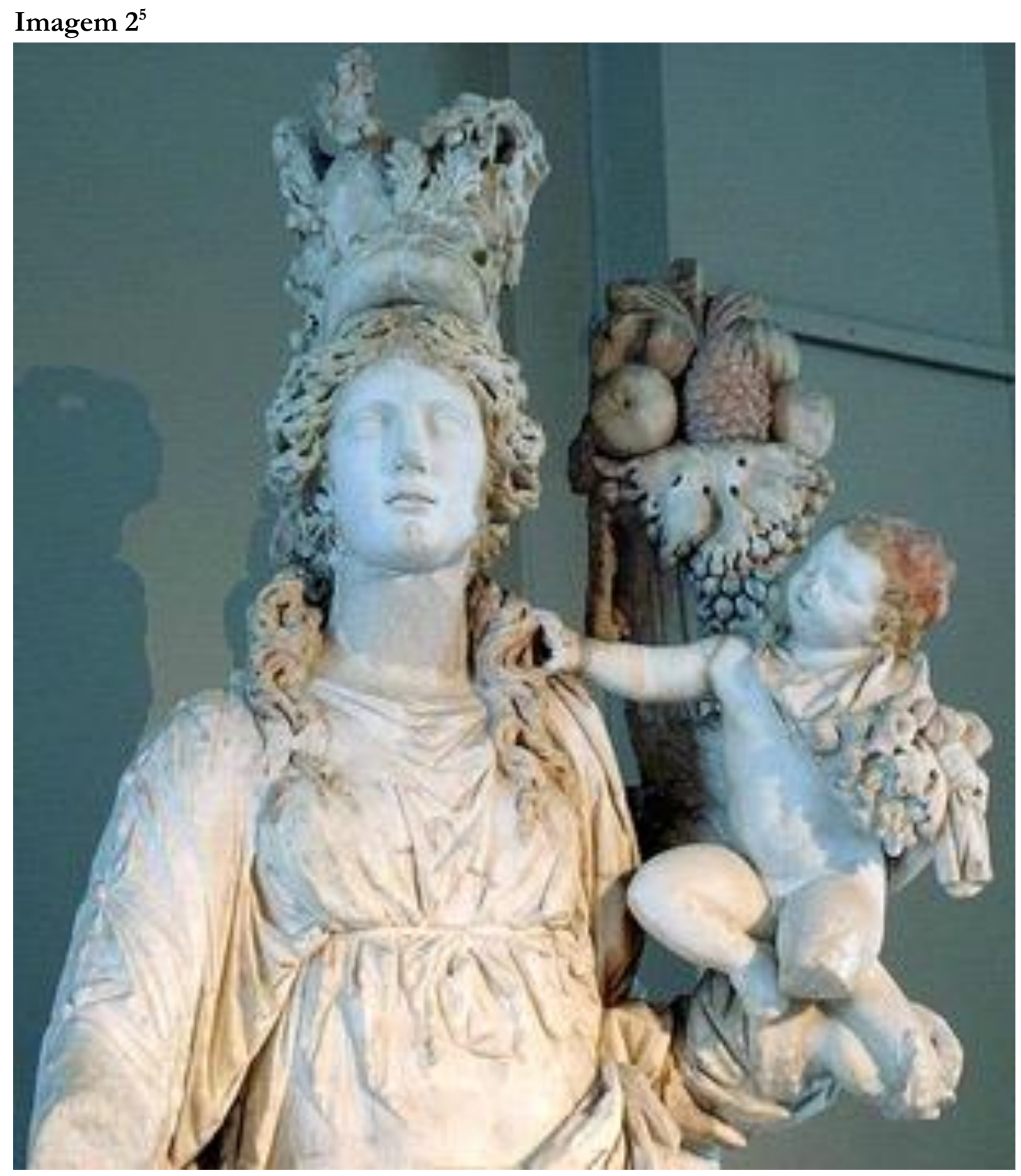

\footnotetext{
${ }^{5}$ Fotografia por petrus.agricola de uma escultura da deusa Tique ou Tyche segurando em seus braços a criança Pluto, o deus da riqueza e da saúde, filho de Deméter, a deusa grega da agricultura e da colheita. Segundo Aristófanes, pelo fato de Pluto ter-se tornado um deus que só distribuía riqueza às pessoas boas, Zeus o castigou cegando-o, de modo que Pluto não mais conseguia distinguir as pessoas boas das más. A escultura é do segundo século depois de Cristo e pertence ao acervo do Museu Arqueológico de Istambul (Turquia). A imagem e as informações acerca dela foram extraídas dos sites seguintes, visitados em 20/08/2020: (https://www.flickr.com/search/?user_id=28433765\%40N07\&view_all=1\&text=Tyche); (https://pt.wikipedia.org/wiki/Pluto_(filho_de_Deméter).
} 


\section{Imagem $3^{6}$}

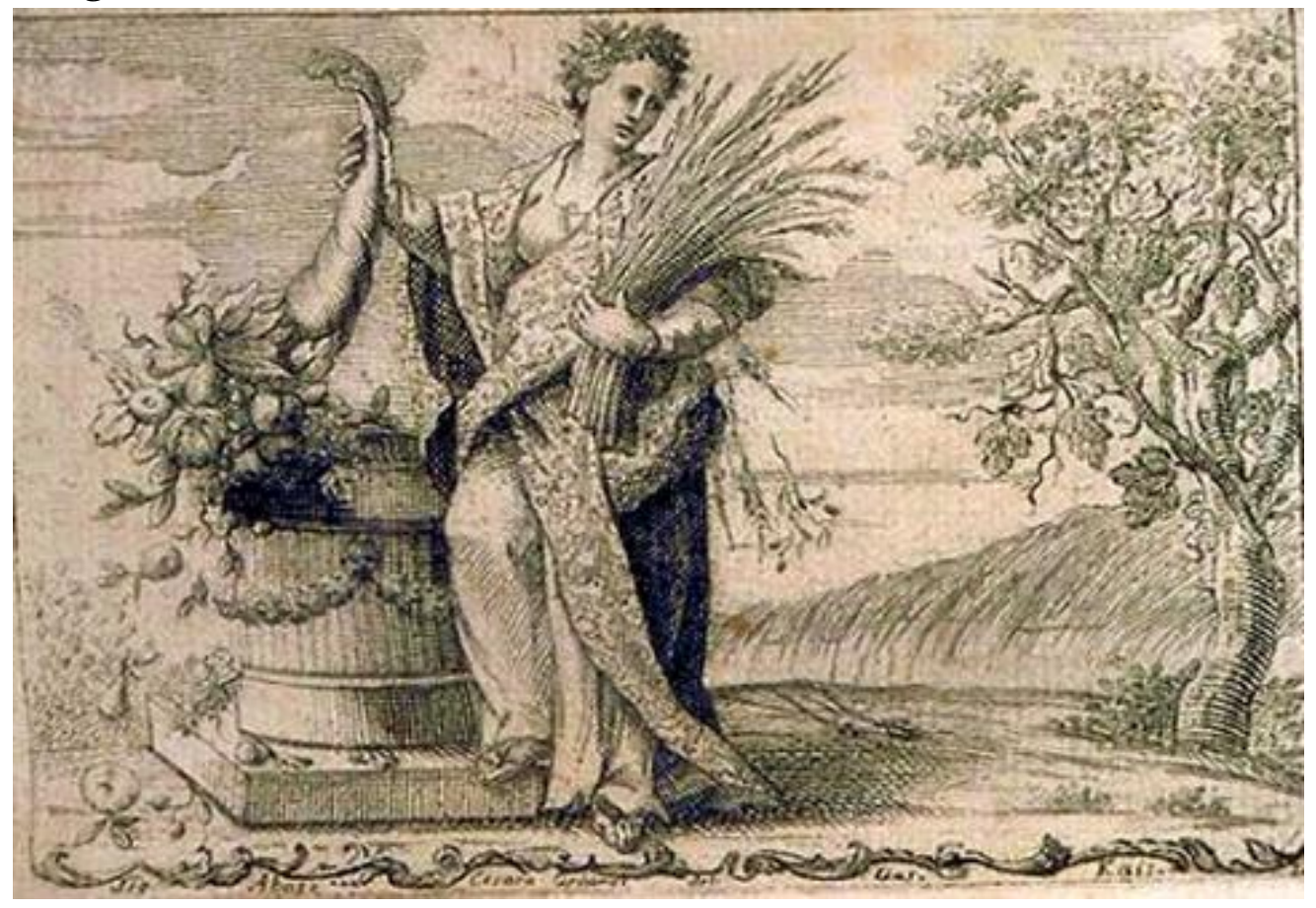

Imagem $4^{7}$

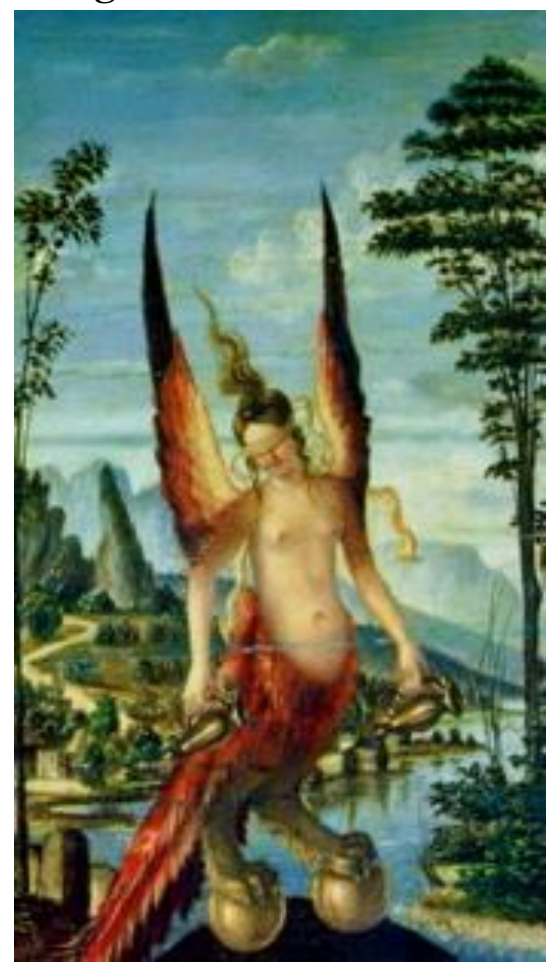

6 Abundância - do escritor e gravurista italiano Cesare Ripa (c.1560 - 1622), autor do livro Iconologia overo Descrittione dell'Imagini universali, Roma (1593) - com cornucópia na mão direita e ramos de trigo na mão esquerda. Fontes da imagem e das informações: (https://pt.wikipedia.org/wiki/Cesare_Ripa);

(https://pt.wikipedia.org/wiki/Ficheiro:Cornucópia_-_A_abundância_(\%22Abb, visitados em 20/08/2020.

7 Óleo sobre tela intitulado Alegoria da Fortuna (1658) do pintor, poeta, músico e ator italiano Salvator Rosa (1615-1673). A obra faz parte do acervo do Museu do Louvre. Fontes acessadas em 20/08/2020: [https://pt.wikipedia.org/wiki/Fortuna_(mitologia)]; (https://pt.wikipedia.org/wiki/Salvator_Rosa). 
$\mathrm{Na}$ imagem $5^{8}$ seguinte, a deusa da Fortuna aparece empunhando um timão ou uma roda de leme de um navio que por se confundir com a roda da fortuna, simboliza o controle do destino das tripulações e das embarcações em suas viagens ameaçadas por riscos diversos, no campo de atividade náutico-marítima. Por extensão metafórica, essa roda simboliza também o ciclo da vida, o controle dos destinos das vidas pessoais e as mudanças de orientação do destino nas histórias das vidas pessoais.

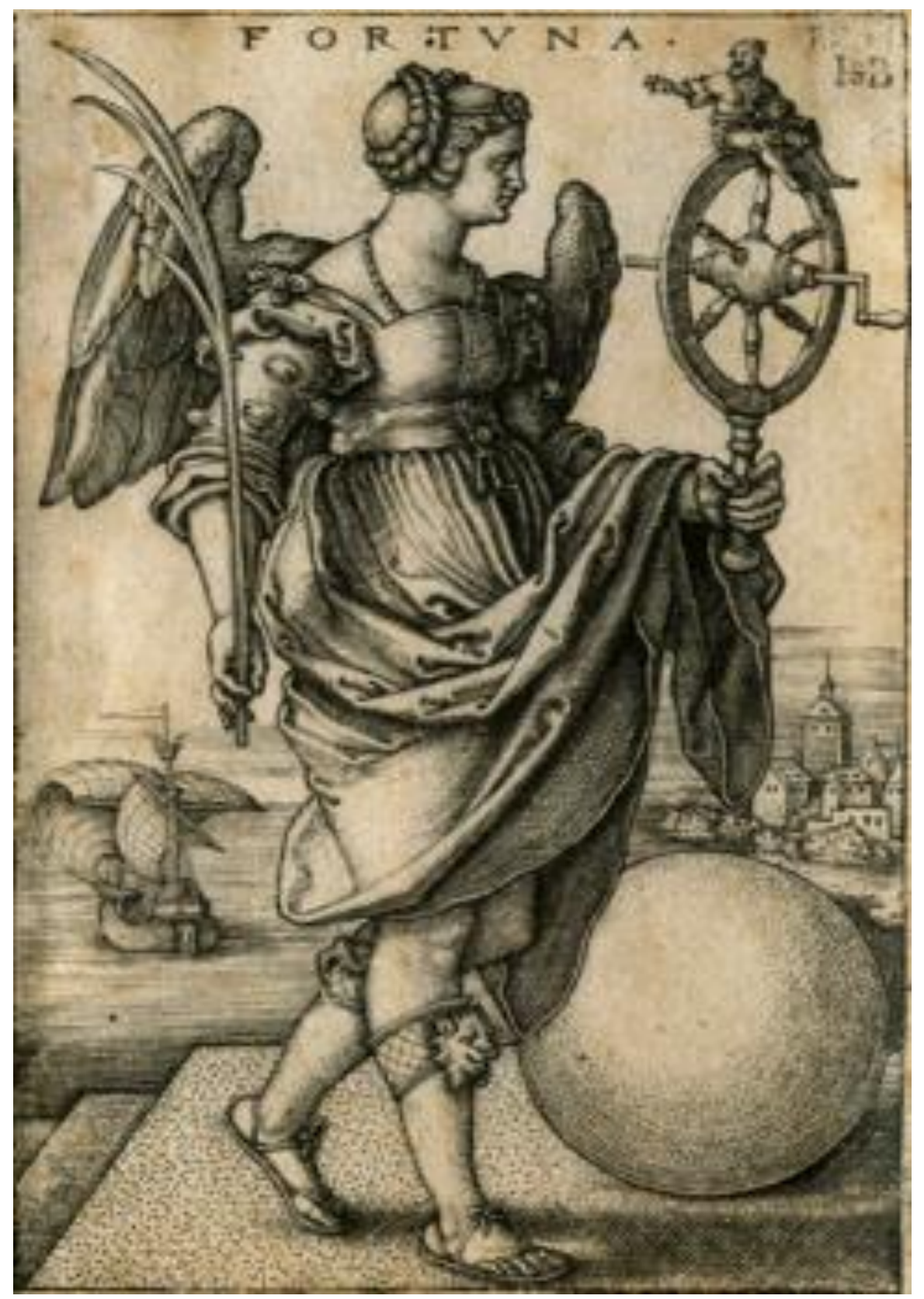

\footnotetext{
${ }^{8}$ Gravura intitulada Fortuna marinha co timão do pintor, artista gráfico e miniaturista alemão Hans Sebald Beham (1500-1550). Fontes: [https://pt.wikipedia.org/wiki/Fortuna_(mitologia)];

(https://pt.wikipedia.org/wiki/Hendrik_Goltzius), visitadas em 20 de agosto de 2020.
} 
$\mathrm{Na}$ imagem $6^{9}$ e na imagem $7^{10}$ seguintes, a deusa Fortuna aparece empunbando a vela de um navio, tendo ao lado - ou pisando sobre - uma esfera, uma outra forma de simbolizar o poder protetor dessa deusa contra os riscos imprevisíveis emergentes no campo de atividade da navegação marítima.

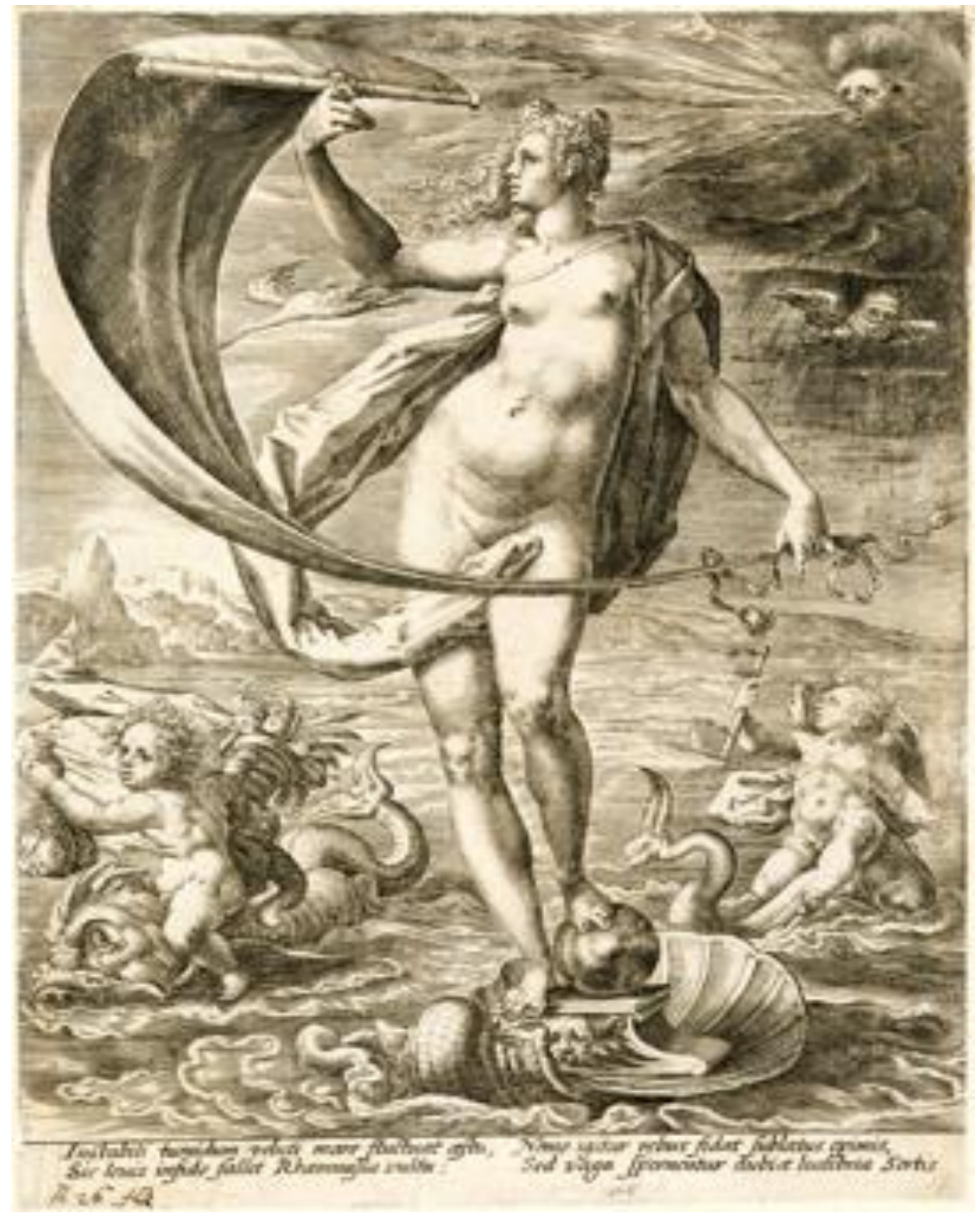

\footnotetext{
${ }^{9}$ Gravura intitulada Fortuna sobre esfera do pintor, desenhista e gravurista holandês Hendrik Goltzius (1558-1617). Fontes: [https://pt.wikipedia.org/wiki/Fortuna_(mitologia)];

(https://pt.wikipedia.org/wiki/Hendrik_Goltzius), visitadas em 20 de agosto de 2020.

${ }_{10}$ Óleo sobre tela intitulado Alegoria da Fortuna $(1615 / 20)$ ou Fortuna Marinha do pintor belga Frans Francken, o Jovem (1581-1642). A obra faz parte do acervo do Museu do Louvre.

Fontes: (https://www.louvre.fr/en/oeuvre-notices/allegory-fortune);

(https://pt.wikipedia.org/wiki/Frans_Francken,_o_Jovem).
} 


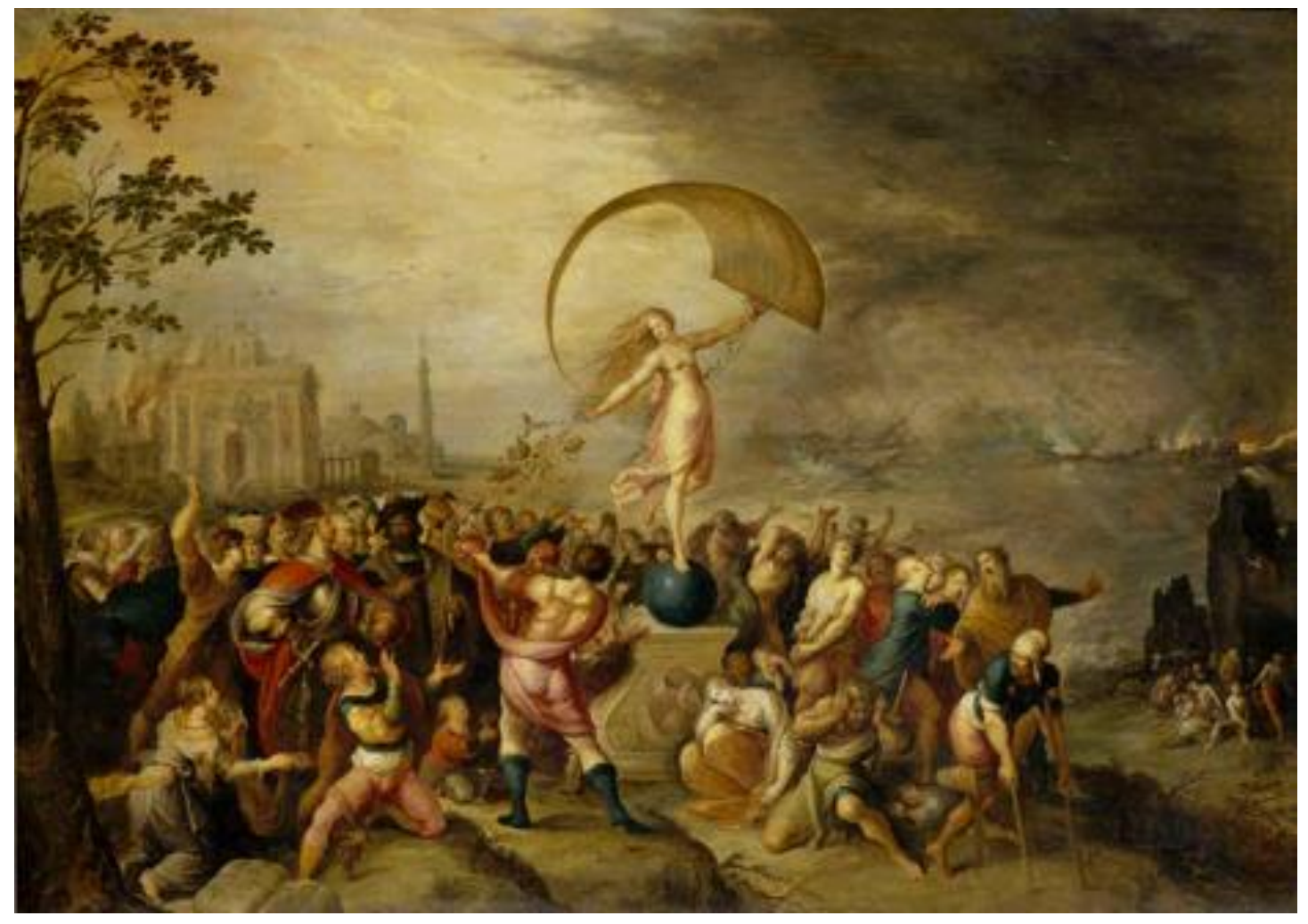

$\mathrm{Na}$ imagem $8^{11}$ seguinte, a deusa Fortuna aparece com asas nos pés, nas costas e/ou nos quadris e longa mecha de cabelos caindo sobre o rosto, simbolizando que o êxito dos empreendimentos humanos depende da persistência e da paciência para se agir no momento oportuno.

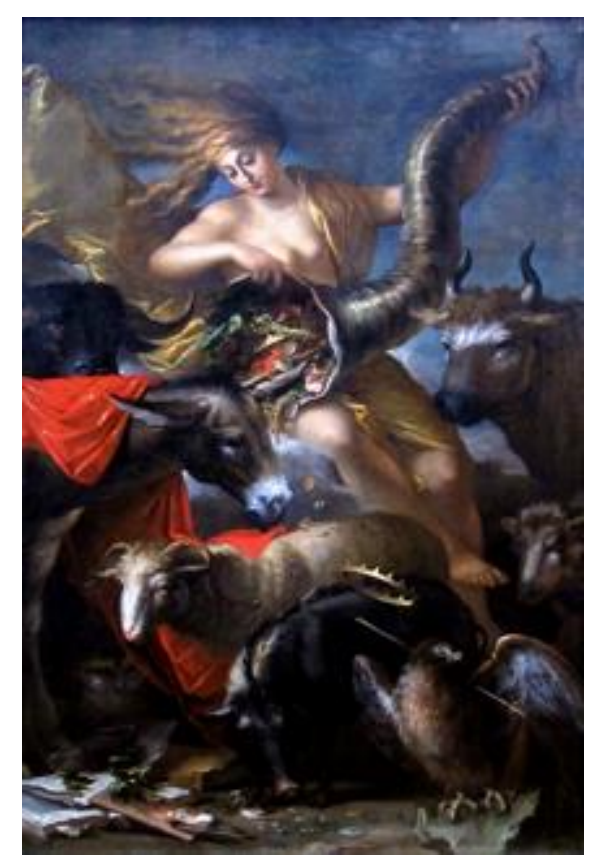

11 Óleo sobre tela Alegoria da Fortuna alada (cerca de 1490) do pintor renascentista italiano Andrea Previtali, também chamado Andrea Cordelliaghi (c. 1480 -1528). Imagem e informações extraídas dos sites seguintes, visitados em 20 de agosto de 2020:

[https://pt.wikipedia.org/wiki/Fortuna_(mitologia)]; (https://en.wikipedia.org/wiki/Andrea_Previtali. 
Já na imagem $9^{12}$ seguinte, a deusa da Fortuna aparece com os olhos vendados e segurando uma coroa em uma das mãos, simbolizando o seu modo imparcial de agir na distribuição aleatória de sortes ou sinistros em seus prognósticos dos destinos das vidas pessoais, das vidas políticas das cidades e dos empreendimentos comunitários.

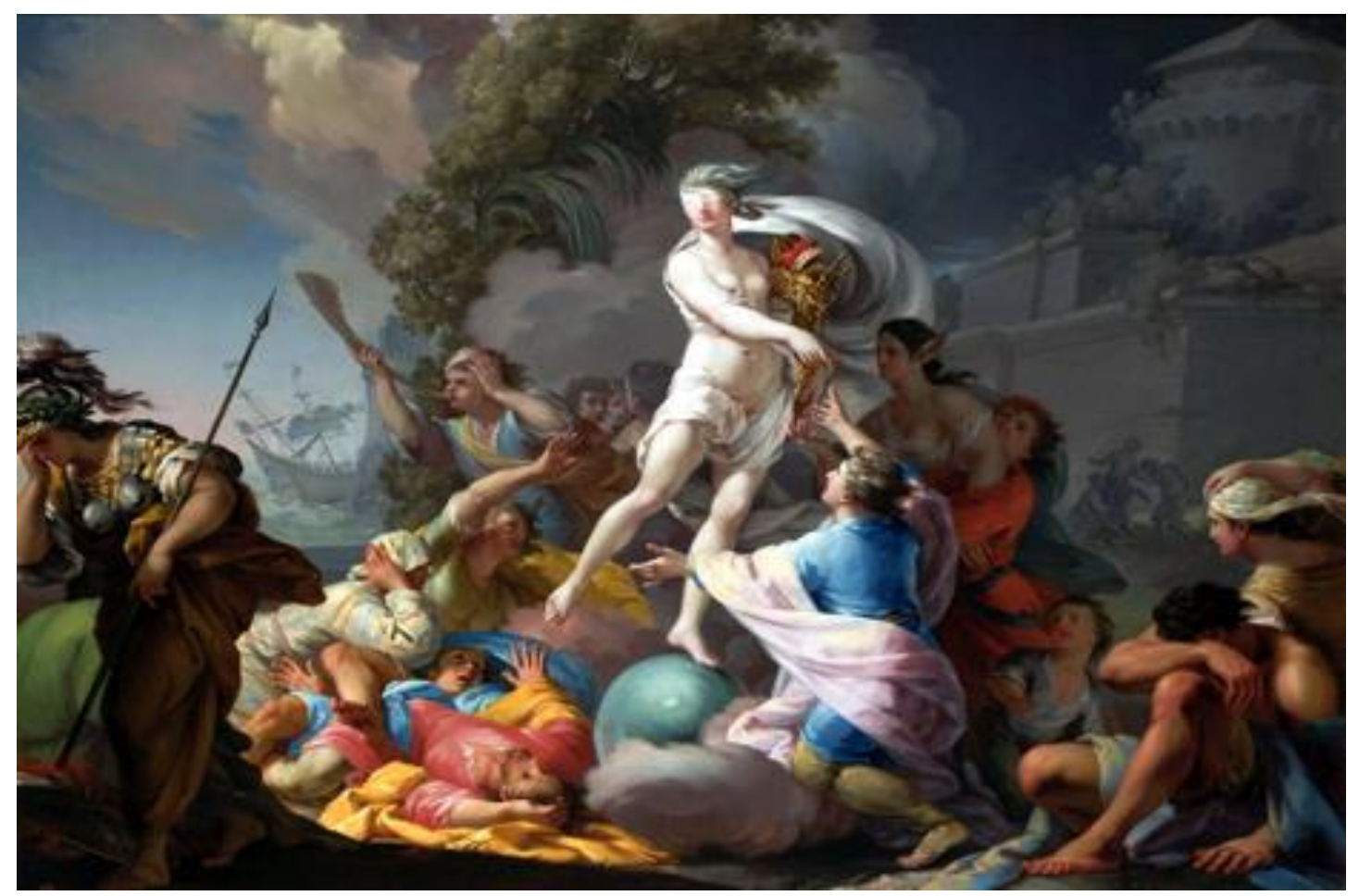

Tais jogos artístico-visuais de linguagem, dentre muitos outros que poderíamos aqui apresentar, quando constituídos como arquivos iconográficos para a investigação de práticas seguradoras na história, mostram-se esclarecedores da diversidade de campos de atividade humana nos quais os seres humanos tiveram que lidar com o problema do acaso, mas não nos indicam se tal problema teria primeiramente se manifestado no campo da navegação marítima, no qual, certamente, a prática da bodemeria foi inicialmente praticada. Para esclarecer esse problema, vamos continuar rastreando tal prática na história.

A prática da bodemeria pode ser melhor descrita através das expressões em língua inglesa que a traduzem, quais sejam, bottomry ou bottomage. No contexto náutico, a palavra inglesa bottom pode ser traduzida e significada como casco de uma embarcação ou navio e as expressões bottomry ou bottomage nomeiam uma prática de financiamento de viagens marítimas em que o proprietário do navio firma um contrato com o financiador da viagem no qual o proprietário hipoteca o próprio navio como forma de proteger o financiador da viagem contra o risco de perda do valor financiado. Assim, a prática da bodemeria pode ser vista como uma prática hipotecária em que o contratante do empréstimo de risco, no caso o proprietário do navio, dá o próprio bem, o navio, como garantia na tomada de um empréstimo pecuniário que irá financiar uma ou mais viagens. Para proteger o seu navio e as mercadorias que ele transporta contra os riscos casuais da viagem, o proprietário do navio precisa recorrer ao capital de um agente financeiro e pagar juros por esse empréstimo de risco, 12 Pintura a óleo sobre tela de 1754, intitulada Fortuna, do pintor italiano Tadeusz Kuntze (1733-1793), acervo do Museu
Nacional de Varsóvia - Polônia. (https://en.wikipedia.org/wiki/Tadeusz_Kuntze). 
ainda que ele lhe esteja assegurado todos os direitos de proprietário, neles incluídas as supostas vantagens e lucros advindos da comercialização das mercadorias que o navio transporta. Mas as palavras inglesas que nomeiam a prática da bodemeria - bottomry ou bottomage - sugerem que essa prática hipotecária de seguro não assegurava propriamente nem as mercadorias transportadas - quando isso ocorria, a prática era nomeada respondentia - e nem o navio como um todo, mas apenas o sen casco ou a sua quilha.

Ver a prática da bodemeria como uma prática bipotecária de seguro que assegura o pagamento de juros para o financiador da viagem de um navio, nos permite também desatrelar as práticas hipotecárias de financiamento pecuniário a juros do campo náutico de atividade humana, no qual ela de fato era praticada, para sugerir que práticas de empréstimos pecuniários a juros, entre os povos antigos, poderia também ter sido praticada em outros campos de atividade humana, independentemente dela estar assegurando algum bem contra sinistros de quaisquer natureza.

Mais do que isso, dado que os registros históricos mais antigos relativos a transações comerciais e financeiras que chegaram até nós estão inscritos em signos numéricos cuneiformes em tabletes de barro produzidos por volta de 3000 anos a.C pelos caldeus e sumérios que viveram no vale da Mesopotâmia (IFRAH, 1989, p. 141-144), é razoável pensar que práticas semelhantes à da bodemeria teriam se originado no campo de atividade financeira que, no mundo antigo, estava atrelado ao campo de atividade comercial. Segundo Ifrah,

[...] esses tabletes contábeis ainda não comportam sinais de escrita, sendo as informações correspondentes exclusivamente simbólicas e numéricas. As coisas designadas pelas operações são neles indicadas apenas por suas quantidades respectivas, e não por signos específicos que permitiriam apreciar a sua natureza. Além disso, a operação propriamente dita não figura neles de nenhuma maneira: tratar-se-ia de uma venda, de uma compra, de um contrato de casamento, de uma distribuição, ou simplesmente do inventário de bens de um proprietário? [...] Por volta de 3200 a.C. aparecem, pouco a pouco, novos signos sobre os tabletes ao lado dos números sumerianos ou elamitas [...] Esta etapa marca o nascimento da contabilidade escrita, pois esses signos (desenhos mais ou menos esquemáticos representando todo tipo de objetos ou seres) destinam-se a precisar a natureza dos gêneros ou mercadorias envolvidos por ocasião desta ou daquela transação (IFRAH, 1989, p. 141-142).

Parece, então, terem sido as atividades comerciais e financeiras os campos nos quais a prática da bodemeria teria tido a sua origem e, em momentos e locais oportunos, sido apropriada e adaptada para se lidar com problemas orientados para se contemplar propósitos sociais diversos em diferentes campos de atividade em que emergiram, tais como: o campo o náutico, o agrícola, o familiar, o religioso, o jurídico, entre outros.

De fato, em um dos tabletes contábeis de barro que remontam aos povos que habitaram o Vale da Mesopotâmia desde, pelo menos, o terceiro milênio antes de Cristo, aparece o seguinte problema: Quanto tempo levaria uma quantia em dinheiro para dobrar, a 20 por cento ao ano? Segundo Boyer ${ }^{13}$ (1974, p. 22), "[...] parece inteiramente claro que o escriba usou interpolação linear entre os valores $(1 ; 12)^{3}$ e $(1 ; 12)^{4}$, usando a fórmula para juros compostos $\mathrm{a}=\mathrm{P}(1+\mathrm{r})^{\mathrm{n}}$, onde $\mathrm{r}$ é $20 \%$ ou $12 / 60$, e tirando valores de uma tabela exponencial com

${ }^{13}$ BOYER, C. B. História da matemática. Tradução Elza F. Domingues. São Paulo: Editora Edgar Blücher Ltda, 1974. 
potências de 1;12". É claro que, o que Boyer está querendo dizer com isso, não é que os povos antigos mesopotâmicos usavam fórmulas algébricas ou as nossas notações numéricas para realizarem os seus cálculos e resolverem problemas matemáticos, mas sim, que tais povos, através de seus próprios sistemas numéricos e regras de operar com os sinais desses sistemas ${ }^{14}$, dispunham também, tal como nós, de um algoritmo, isto é, de um procedimento normativo que, quando seguido à risca, levava à solução do problema, no caso, de um método de interpolação de números auxiliado por uma tabela exponencial com potências de (1;12), isto é, de uma tábua que fornecia os resultados da operação da elevação sucessiva da base 0,2 a vários expoentes. Mediante tais expedientes de cálculos e método de interpolação, os escribas mesopotâmicos conseguiam resolver problemas que envolviam juros compostos com precisão não só para os casos em que os empréstimos contraídos fossem pagos após um número inteiro de anos, mas também quando fossem pagos após $x$ anos, $y$ meses e $d$ dias.

Mas, se por volta do terceiro milênio antes de Cristo, certas comunidades de prática - a dos escribas, por exemplo, que realizavam a prática cultural especializada da escrita não alfabética e da escrita numérica contábil de base sexagesimal em tabletes de barro e em esferas de argila emergentes entre alguns povos antigos já sabiam resolver problemas de empréstimos a juros compostos, então, é razoável supor que práticas hipotecárias de financiamento pecuniário a juros já se realizavam antes mesmo do terceiro milênio antes de Cristo em conexão a problemas emergentes em diferentes campos de atividade humana - e que, portanto, a prática da bodemeria que se realizava em estrita conexão com o campo de navegação marítima, já se realizava bem antes da escrita do Código de Hamurabi (cerca de 1800 a.C.) que a ela, como vimos, dedica algumas cláusulas. Pois uma prática cultural deve ter sido reiteradamente realizada antes da sua nomeação, dado que atribuir um nome a uma ou a um conjunto de práticas semelhantes é reconhecer a sua relevância e eficácia culturais na contemplação do propósito social por ela previsto para uma ou mais comunidades de prática de uma sociedade, ou mesmo, para toda a sociedade.

\section{A autonomização das práticas financeiras}

Dada a longevidade do campo da navegação marítima, sobretudo associada às necessidades do comércio e da abertura de novas rotas comerciais marítimas, e de ter ele se constituído em estreita conexão com os campos comercial e financeiro de atividade humana, é tentador ver a prática da bodemeria - que desde tempos muito remotos já havia recebido um nome - como a precursora de todas as demais práticas seguradoras de prevenção contra riscos associados a fenômenos aleatórios diversos.

Embora práticas comerciais e financeiras tenham sido realizadas desde o advento das primeiras sociedades humanas sedentárias em que os meios de produção da vida e os bens acumulados haviam se tornado propriedades familiares privadas, elas se intensificaram a partir do século XII, levando ao colapso o mundo medieval.

Foram tais práticas que motivaram e financiaram as Grandes Navegações empreendidas por países europeus nos séculos XV e XVI e instauraram, nesse continente,

\footnotetext{
${ }^{14}$ Boyer utiliza a notação $(1 ; 12)$ para traduzir, por meio dos sinais e das regras de nosso sistema de numeração decimal, os sinais (apenas dois sinais: uma cunha vertical e outra horizontal) e as regras que orientavam a escrita numérica no sistema sexagesimal posicional dos povos mesopotámicos antigos. Assim, $(1 ; 12)^{3}=\left(1.60^{0}+12 \cdot 60^{-1}\right)^{3}=(0,2)^{3}=0,008 . \mathrm{E}(1 ; 12)^{4}=$ $(0,2)^{4}=0,0016$.
} 
um novo modo de produção da vida, agora baseado no capitalismo financeiro-mercantil que patrocinou o tráfico comercial de povos negros africanos para trabalharem como mão de obra escrava nas terras então conquistadas do continente americano. Do século VII ao século XV, a República de Veneza, bem como outras cidades litorâneas italianas tais como Amalfi, Pisa e Gênova, detiveram o monopólio do comércio europeu com o Oriente Médio.

Foram os reis dessas cidades-estados monárquicas que, associando-se ou não aos grandes comerciantes burgueses que haviam acumulado um capital suficiente para disponibilizá-lo a altos juros a navegadores comerciantes que se aventuravam a embrenharse em alto mar em busca de novas rotas marítimas para o reestabelecimento do comércio de seda, especiarias, incensos, drogas medicinais e ópio que financiavam os navegadores.

Esses produtos extremamente caros e necessários no mundo europeu - pois eram usados tanto como cosméticos, aditivos alimentares, conservantes, quanto como em rituais religiosos e como medicamentos no combate a doenças diversas e a epidemias frequentes eram todos importados dos continentes asiático e africano. Porém, eram os comerciantes muçulmanos descendentes de navegadores árabes que dominavam as rotas de navegação no Oceano Índico e que eram também as rotas comerciais de tais produtos.

Quando o Império Otomano tomou a cidade de Constantinopla (a antiga Bizâncio e a atual cidade de Istambul, na Turquia) em 1453, uma das primeiras providências do sultão Maomé II foi a de fechar aos europeus as rotas comerciais marítimas e terrestres para tais produtos, o que fez com os seus preços disparassem, fato este que agravou ainda mais as economias das cidades-estados europeias que já carentes de metais preciosos como o ouro e a prata, passaram a ter que arcar com o pagamento exorbitante do comércio indireto com o mundo oriental para se ter acesso a essas mercadorias, dado que o comércio direto havia sido barrado.

Foi, então, a escassez de ouro e prata e o desmoronamento do sistema econômico medieval altamente descentralizado, ruralizado e baseado na servidão que levou à criação, por parte da parcela abastada de comerciantes burgueses transformados em banqueiros, de um sistema bancário complexo e autônomo para gerenciar os riscos envolvidos no comércio e na navegação. Foi este o momento histórico de emergência de um campo de atividade especificamente financeira relativamente independente do campo de atividade comercial e marítima. Surgia, assim, sobretudo nas cidades da Itália renascentista, uma comunidade de banqueiros burgueses capitalizados e capitalistas, destacada da comunidade até então indistinta de burgueses comerciantes e navegadores, que passaram a financiar as atividades comerciais e marítimas desejosos de ampliar o seu capital, mas também, assumindo os riscos implicados por tal desejo.

Os embates ideológicos cada vez mais frequentes entre a moral religiosa católicocristã, por um lado, e comerciantes e navegadores, por outro, conflitos estes provocados por modos diferentes de se conceber os lucros e as vantagens financeiras que determinadas pessoas obtinham às custas do trabalho efetivo de outras - a moral católico-cristã os via como usura, ao passo que os comerciantes e navegadores como condição para o exercício do seu trabalho - fizeram com que as então milenares práticas seguradoras passassem por novos controles jurídico-normativos. Essa atualização se fazia necessária, dado que os conflitos contratuais envolvendo as práticas seguradoras no continente europeu no mundo moderno eram de natureza distinta daqueles que a elas se manifestavam para os povos da Antiguidade. 
Isso ocorria não apenas porque tais práticas tinham que se adequar às novas regras do jogo político e econômico capitalista-mercantil com o qual se envolvia a Europa no início da era moderna, mas também porque a nova ética mercantilista instaurada por esse jogo entrava em conflito direto com a ética católico-cristã que, por mais de um milênio, havia se tornado hegemônica em todo o continente europeu.

É nesse contexto que surge uma nova prática seguradora e preventiva de riscos denominada contrato de dinheiro a risco marítimo. Tratava-se de um contrato "formalizado entre um emprestador - ou um conjunto de emprestadores - e o navegador. Se, durante a viagem, o barco fosse perdido, o dinheiro era devolvido com o "prêmio" combinado" (CAVICCHINI, 2008, p. 18).

Essa prática foi condenada pelo Papa Gregório IX, o que levou os emprestadores a desenvolverem formas de se adaptá-la para retirá-la da rota da crítica da igreja católica:

Assim, os capitalistas [emprestadores] deixaram de fazer empréstimos e tornaram-se compradores de embarcações e das mercadorias transportadas. Se o navio naufragasse, o capitalista perdia dinheiro; se a viagem tivesse êxito, a cláusula de compra era anulada e o capitalista recebia uma quantia como pagamento pela operação" (GUIMARÃES, 2004, p. 6-7).

$\mathrm{Na}$ realidade, esse embate ético, político e jurídico não pode ser reduzido a uma luta entre valores e propósitos sociais diversos de apenas dois segmentos sociais. O momento era bem mais complexo:

Quando Ponocrato se encarregou da educação do jovem Gargântua, imediatamente lhe deu de beber a água do eléboro, "para que se esquecesse de tudo quanto havia aprendido com os seus preceptores". Rabelais (1483-1553) expressava deste modo, pela boca de seus personagens, as aspirações mais íntimas da burguesia renascentista diante das tradições do feudalismo católico. [...] E que outra coisa desejava também Lutero? [...] Se, dentro do movimento humanista cabiam posições tão distintas, precisamos reconhecer que a designação é vaga, e que se presta a confusões. Onde a burguesia havia alcançado certo esplendor, como em Florença, por exemplo, desenvolveu-se também a "ala esquerda do movimento humanista. A volta ao paganismo que, de certo modo, pode ser considerada a sua bandeira, também significava um resoluto desacato à Igreja Católica, na medida em que esta constituía a sintese e a sanção do poderio feudal. Por outro lado, onde a burguesia se mostrava débil, como acontecia na Alemanha, a "ala direita" do mesmo movimento humanista só chegou a formular a necessidade de uma reforma dentro da Igreja. [...] "Reformadores", "pagãos", ou "católicos tíbios", os humanistas expressavam confusamente as transformações que o nascente capitalismo comercial impunha à estrutura econômica do feudalismo (PONCE, 1983, p. 113-114, grifo nosso).

Foi esse quadro conflituoso deflagrado por uma diversidade de interesses e propósitos sociais em jogo que, em 1310, estabeleceu-se em Bruges - atual capital da província belga de Flandres - uma Câmara de Seguros "[...] que efetuava o registro de todos os contratos de seguro negociados e arbitrava entre as partes, em caso de litígio" (GUIMARÃES, 2004, p. 7).

Ao longo dos séculos XIV e XV, o campo de atividade do comércio marítimo foi o que motivou a adaptação de antigas práticas de seguro, bem como, com base nelas, a invenção de novas práticas: 
O seguro, antes restrito às embarcações, incluía agora o seguro de vidas, limitado aos escravos, que representavam grandes somas de capital" (CAVICCHINI, 2008, p. 18, grifo nosso).

Esta nova modalidade de prática seguradora, em que o bem assegurado passa a ser o próprio corpo humano, parece ter surgido neste momento histórico em que corpos negros trazidos de África passam a ser explorados e comercializados como mão de obra escrava nas terras ameríndias colonizadas "descobertas" pelo empreendimento marítimo-comercial europeu. Assim, esta "nova" prática seguradora se constitui se espelhando nas antigas práticas de seguros de mercadorias, uma vez que corpos negros escravizados passam a ser considerados propriedades no mercado mercantil-capitalista europeu.

Algumas práticas passaram a ser juridicamente criminalizadas:

[...] os homens não estão incluídos nos termos da mercadoria; um homem livre não pode ser comprado e vendido; a um homem livre não pode ser atribuído um valor (HALD, 2003, p. 118).

Tal como entre os povos da Antiguidade, as práticas seguradoras não se restringiam ao campo de atividade comercial, mas eram também realizadas no campo de atividade agrícola em que há riscos de perda por desastres climáticos, pragas, enchentes ou escassez de chuvas:

$\mathrm{Na}$ itália, por exemplo, os agricultores criavam cooperativas agrícolas para proteger uns aos outros contra as intempéries; os agricultores de áreas com uma estação de boas colheitas concordavam em indenizar as vítimas de um clima menos favorável (BERNSTEIN, 2011, p. 96)

Em 1318, um primeiro contrato relativo a uma prática de seguro marítimo sobre transporte de mercadorias entre as cidades de Pisa e Sardenha é documentado, sendo tal contrato nomeado assecuramento de poliza, isto é, política de seguros, expressão esta da qual se originou o termo apólice utilizado em nossos dias, no campo de atividade atuarial, para denominar um contrato de seguro. O termo apólice parece ter sido utilizado, pela primeira vez, em Londres, em 1583 (CAVICCHINI, 2008; GUIMARÃES, 2004).

E a um tal incremento e promoção das atividades náuticas devido à necessidade de se buscar novas rotas comerciais marítimas correspondeu um aumento proporcional de práticas de seguros de navios e de mercadorias que eles transportavam, o que levou alguns mercadores a transformar essas próprias práticas em mercadorias. Surgiu, desse modo, em Gênova, a primeira comunidade de mercadores livres especializados na produção, promoção e venda de contratos de seguros náuticos a navegadores, de modo que, já em 1434, tal atividade foi regulamentada como uma profissão:

Em 1434, uma lei genovesa regulava as atividades de bancadores, armadores e corretores. Os seguros foram designados com os termos de securare, sigurare ou ainda assicurare (CAVICCHINI, 2008, p. 19).

A partir do advento de uma tal comunidade de corretores de seguros, práticas de cosseguro começam também a se tornar frequentes. Tais práticas consistiam no 
cofinanciamento assegurado da viagem de um mesmo navio por parte de vários financiadores-seguradores (CAVICCHINI, 2008). No ano de 1500, foi até mesmo publicada a obra "Guia para os comerciantes do Mar", na qual tais práticas de comercialização de seguros e cosseguros náuticos passaram a ser descritas e disseminadas para outras cidades italianas e europeias. As próprias viagens de Cristóvão Colombo foram financiadas pela empresa de Américo Vespúcio com base em práticas de cosseguros. (CAVICCHINI, 2008).

Em Portugal, as práticas de seguros estavam intrinsecamente ligadas às atividades náuticas. A primeira Lei sobre seguros, datada de 1370, obrigava navios com mais de 50 toneladas a participarem de mútuos, pois os riscos no Atlântico, envolvendo pirataria e tempestades, por exemplo, eram altos. Também em Portugal, em 1529, a Carta Régia criou a profissão de escrivão de seguros. Neste contexto, é formada a primeira sociedade corretora, em 1680, Hudig-Langeveldt, atuante no mercado desde 1680 até 1991, quando se incorporou à AON Corporation (CAVICCHINI, 2008).

Em 1503, a Rainha Isabel de Castela cria, em Sevilha, a Casa de Contratação das Índias, com o propósito de fomentar o comércio com o novo mundo. A princípio, as negociações que envolviam seguros eram feitas nessa instituição, mas à medida que as negociações aumentaram, foi criado, para cumprir tal propósito, o Consulado dos Mercadores na Casa Lonja, conhecido como Bolsa, cujas atividades eram financiadas com fundos provenientes da corretagem de seguros, sendo que parte dos lucros obtidos pelas atividades desenvolvidas por essa instituição era destinada para a organização e financiamento das atividades de uma armada para a proteção de navios, cujo propósito era o de combater ataques de piratas e corsários, de modo a diminuir os riscos das viagens provocados por fatores não-aleatórios (CAVICCHINI, 2008).

$\mathrm{Na}$ Inglaterra, as práticas de seguro também foram realizadas em estreita conexão com as atividades náuticas. Contudo, a primeira sociedade de companhia de seguros surgiu, nesse país, para assegurar riscos contra incêndios. Após o grande incêndio de Londres ocorrido em 1666, que destruiu 44 prédios públicos, 87 igrejas e 13.200 casas, totalizando $1 / 3$ da capital britânica, surgiu a Insurance Office, com suas brigadas contra incêndios, instituição esta que deu origem ao Corpo de Bombeiros (CAVICCHINI, 2008).

Guimarães destaca que a criação de companhias de seguro marcou o início de novas práticas envolvendo riscos terrestres, não necessariamente vinculados ao comércio ou à vida.

A história dos seguros marítimos na Inglaterra está associada fortemente à história de uma casa de café. Na década de 1680, foi fundado o Lloyd's Coffe House, que de acordo com Cavicchini, por disponibilizar informações atualizadas e precisas sobre os navios atracados no porto, se tornou o principal ponto de encontro de navegadores e empreendedores interessados em assegurar negócios marítimos. Bernstein detalha como essas práticas ocorriam no café:

Reconhecendo o valor de sua base de clientes e respondendo à insistente demanda por informações, em 1696, [Edward Lloyd] lançou a Lloyd's List, recheando-a de informações sobre as chegadas e partidas de navios e as condições no exterior e no mar. Tais informações eram fornecidas por uma rede de correspondentes nos principais portos da Europa continental e Inglaterra. Leilões de navios ocorriam regularmente nas dependências do café, e Lloyd fornecia obsequiosamente o papel e a tinta necessários ao registro das transações. Um canto estava reservado aos capitães dos navios, onde podiam trocar informações sobre os riscos de todas as novas rotas que se abriam - rotas 
que os levavam para mais longe do que nunca a leste, ao sul e a oeste. O estabelecimento de Lloyd ficava aberto quase 24 horas por dia e estava sempre apinhado (BERNSTEIN, 2011, p. 93-94).

As práticas eram similares às atuais de busca por seguros. Os interessados, de acordo com Bernstein, procuravam por corretores que ofereciam o risco aos enfrentadores de riscos que se reuniam em locais como o Lloyd's Coffe House. Esses últimos passaram a ser conhecidos como underwriters:

Quando um negócio era fechado, quem assumia o risco confirmava sua concordância em cobrir o prejuízo em troca de um prêmio específico assinando seu nome sob (under) os termos do contrato; logo esses operadores de seguros individuais passaram a ser chamados de underwriters (BERNSTEIN, 2011, p. 93).

Cavicchini destaca que entre 1690 e 1720 o comércio marítimo inglês teve um crescimento significativo e, com ele, a demanda por seguros também aumentou. Neste contexto, foram fundadas por underwriters, a fim de diminuir a concorrência, duas companhias de seguros: Royal Exchange Assurance Corporation e a London Assurance. Essas companhias, de acordo com Bernstein, passaram por "[...] dificuldades pela incapacidade de persuadir seguradores experientes a trabalhar nelas" (BERNSTEIN, 2011, p. 94). Por fim, essas empresas se especializaram em seguros contra incêndios, por ter tal modalidade de seguro Cavicchini (2008), uma maior demanda e o risco mais distribuidos do que os riscos náuticos que continuaram sendo praticados pelos underwriters.

$\mathrm{Na}$ década de 1750, o Lloyd's adquiriu a fama de ser um local onde se fazia fortuna. De acordo com Bernstein, o "espírito de jogatina" atraiu várias personalidades para o local, incluindo apostadores e bookmarkers, fomentando um mercado de apostas "[...] que ia desde 'quando ia morrer' uma personalidade pública que a imprensa noticiava como doente até o próximo navio a afundar" (CAVICCHINI, 2008, p. 39). Bernstein também destaca que esse cenário gerou emissão de diversas apólices de seguros que iam muito além dos marítimos:

Os seguradores estavam dispostos a emitir apólices de seguros contra quase todo tipo de risco, inclusive, segundo um relato, roubos em residências, roubos nas estradas, morte por excesso de gim, morte de cavalos e 'seguro da castidade feminina' dos quais todos, exceto o último, ainda são seguráveis (BERNSTEIN, 2011, p. 93).

Cavicchini marca, nesse contexto, a fundação do New Lloyd's Coffe House, em 1769, por 79 dos mais importantes underwriters que se afastaram do local. Em 1771, quase cem anos após a abertura do Lloyd's Coffe House, Bernstein destaca a criação da Society of Lloyd's, um grupo que operava sob um código de conduta, e que passou a ser conhecido como Names. Essa sociedade ganhou tamanha importância que se instalou, em 1774, no Royal Exbange Building, mesmo local onde funcionava a bolsa de valores:

Os Names empenhavam todos os seus bens terrenos e todo seu capital financeiro para cumprir a promessa de cobrir os prejuízos dos clientes. esse empenho foi uma das principais razões do rápido crescimento dos negócios fechados na Lloyd's no correr dos anos" (BERNSTEIN, 2011, p. 94). 
Com o passar dos anos, o Lloyd's passou a atuar em diferentes campos de atividade. Em 1871, de acordo com Cavicchini (2008), foi iniciada uma operação em resseguros, uma atividade que, até então, era vista como uma forma de jogo pelas autoridades, considerada de "má-fé". Em 1887, Cavicchini (2008) assinala o surgimento da primeira apólice de seguro não-marítimo da história do Lloyd's, subscrita por Cuthbert Heath.

Grande parte da credibilidade atribuída ao Lloyd's pode ser atribuída, de acordo com Cavicchini (2008), a dois grandes sinistros que, apesar de terem causado grandes prejuízos aos underwriters, foram pagos corretamente. O primeiro sinistro que marcou a história da seguradora foi o terremoto de 1906, que causou desastres enormes na Califórnia. O outro foi o naufrágio do Titanic, em 1912, que causou a morte de mais de 1500 pessoas, que havia sido segurado no valor de 1 milhão de libras ${ }^{15}$.

Os campos de atuação do Lloyd's continuaram sendo expandidos. Em 1905, Cavicchini (2008) marca o surgimento da primeira apólice de seguro automotivo subscrita por underwriters. Em 1911, a primeira apólice de avião. Até os dias atuais, o Lloyd's continua a atuar como um mercado de seguros, não uma companhia, atuando como uma ponte entre o underwriter e os clientes, e cujo principal campo continua sendo o mercado marítimo:

Os clientes procuram uma corretora (broker) do Lloyd's que descreve minuciosamente todos os riscos envolvidos no seguro do bem e procura, entre os sessenta e seis sindicatos de underwriters, o que oferece o preço mais vantajoso para a transação (CAVICCHINI, 2008, p. 40-41).

\section{A judicialização das práticas seguradoras}

O que esta breve descrição do advento, na Europa moderna, de novas práticas, de novas comunidades de prática e de novas instituições seguradoras no campo náutico nos mostra é que ele decorreu, sobretudo, do processo de autonomização das práticas financeiras oportunizada por um novo modo de organização da vida econômica, social e política baseada na ética mercantil-capitalista.

Paralelamente a esse movimento febril de invenção e proliferação de novas práticas seguradoras em diferentes campos de atividade humana, assiste-se também, desde a Antiguidade, um duplo movimento de controle normativo de tais práticas: um movimento de controle lógico-normativo que se caracteriza pelo esforço e empenho humano de se tornar cada vez mais preciso, rigoroso e inequivoco o controle sobre os eventos aleatórios geradores de sinistros que colocam em risco os propósitos sociais orientadores de diferentes atividades humanas consideradas vitais; um movimento de controle jurídico-normativo que se caracteriza pelo esforço e empenho humano de se tornar cada vez mais adequadas e justas as leis que regulam os diferentes conflitos que se manifestam nos acordos que humanos estabelecem entre si para se viabilizar a realização de práticas de risco que permitem contemplar os propósitos de tais atividades consideradas vitais.

Se práticas de nomear uma prática ou um conjunto de práticas semelhantes são sempre posteriores à demonstração da eficácia de uma prática para se lidar com um ou mais problemas semelhantes

\footnotetext{
${ }^{15}$ Informação extraída da matéria publicada no site (https://www.lloyds.com/lloyds/about-us/history/catastrophes-andclaims/titanic), acessado em 15 de maio de 2020.
} 
que emergem em um ou mais campos de atividade humana, práticas de judicialização de uma prática só emergem no campo social não propriamente para se lidar com o problema da maior ou menor eficácia de uma prática em se lidar satisfatoriamente com um problema, mas para se lidar com o problema do poder de uma prática de gerar novos problemas, do seu poder de gerar conflitos imprevistos ou relaçoes assimétricas de poder ao nível interpessoal, isto é, entre as pessoas envolvidas com essa prática e que, provavelmente, estabeleceram um contrato ou acordo mútuo baseado em regras meramente verbais que não previram que eventos inesperados pudessem vir a desestabilizar o acordo estabelecido.

No caso específico da prática de bodemeria, a sua judicialização - e, portanto, a necessidade de se produzir leis escritas regulamentando os critérios legais considerados justos para se apaziguar conflitos entre os contratantes mútuos dessa prática -, só poderia ter ocorrido após a constatação vivencial, por um longo período de tempo, por parte de muitos praticantes dessa prática, da ocorrência de muitos conflitos imprevistos entre bumanos assinantes mútuos de um contrato de risco justamente feito para se precaver contra riscos mútuos imprevistos entre bumanos e os poderes casuais das intempéries naturais.

Percebeu-se, então, que os eventos naturais sinistros e imprevisiveis que punham em risco tanto o bem material "navio" (da pessoa que contraía o empréstimo) quanto o bem material "dinheiro" (da pessoa que financiava a viagem) eram os mesmos eventos naturais sinistros $e$ imprevisiveis que desestabilizavam o contrato de risco realizado entre as partes, justamente para se precaverem mutuamente contra riscos. Daí a necessidade de se levar a prática da bodemeria ao controle dos tribunais judiciais, transferindo o controle do duplo poder produtivo de caráter destrutivo do man acaso - o de destruir navios e o de abalar as relações interpessoais - ao poder de controle normativo, convencional e apaziguador dos juristas.

Há evidências históricas de que a prática da bodemeria continuou a ser realizada no continente europeu pelo menos até o século XIX e de que a sua regulamentação jurídica não teria se dado sem conflitos, a ponto de tal prática ter sido até mesmo objeto de dissertação acadêmica. De fato, a figura abaixo é a capa de uma dissertação acadêmica produzida no campo jurídico que tomou como objeto de discussão exatamente tal prática.

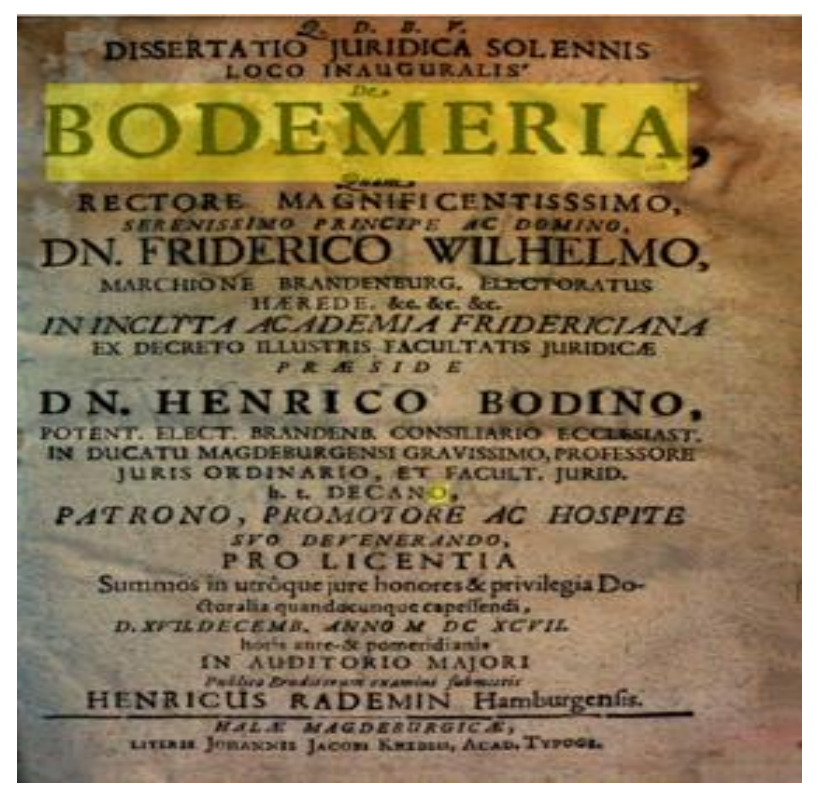


Essa dissertação ${ }^{16}$ de autoria de Henricus Rademin Hamburgensis (HAMBURGENSIS, 1697), dedicada ao príncipe Friederico Wilhelmo, foi defendida em dezembro de 1697 na Faculdade Jurídica de Brandemburgo (Alemanha) e presidida pelo magistrado Henrico Bodino. Nela, o seu autor trata a prática da bodemeria exclusivamente no interior do campo de atividade náutica.

O mesmo não ocorre no livro português publicado em 1830 sob o título Synopsis Juridica do Contracto de Cambio Marítimo vulgarmente denominado Contrato de Risco (BORGES, 1830) ${ }^{17}$, ainda que o seu autor, Jose Ferreira Borges, empregue a palavra bodemeria como sinônimo de câmbio marítimo, conforme a foto abaixo, da página de rosto dessa obra, o atesta, definindo como aleatório o contrato de câmbio marítimo, denominado pelos povos antigos de ganho ou interesse náutico:

\section{SYNOPSIS J U RIDICA}

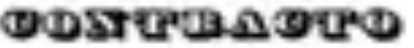

\section{Cambio ftaritimo}

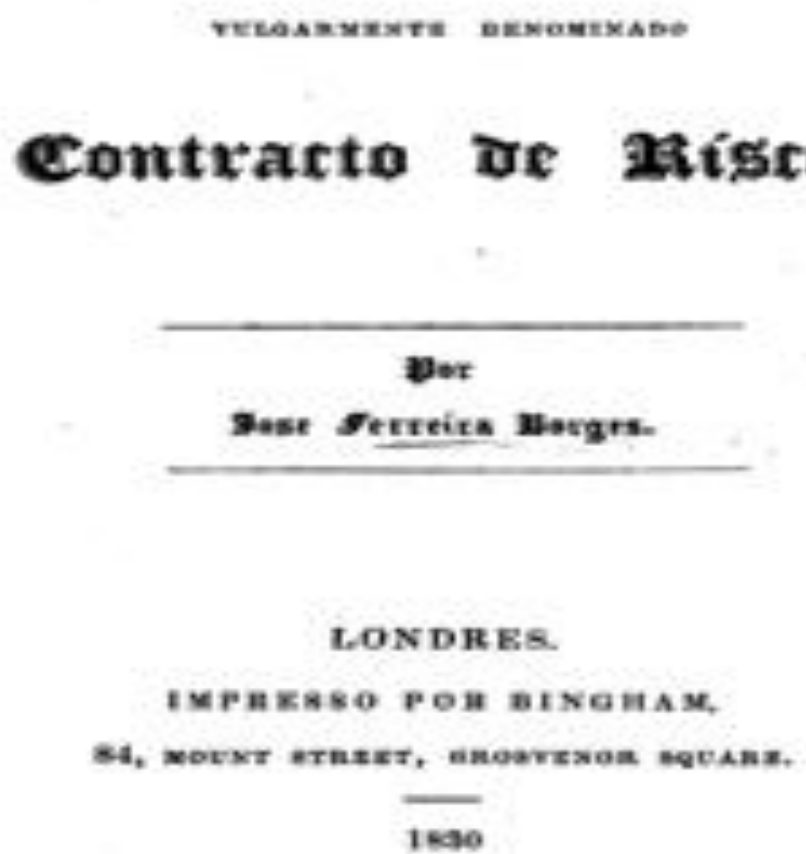

16 O texto completo em latim dessa dissertação está disponível, na íntegra, no link (https:/ / books.google.com.br/books?id=R0FJAAAAcAAJ\&printsec $=$ frontcover\&source $=$ gbs_atb\&redir_esc $=\mathrm{y} \# \mathrm{v}=\mathrm{O}$ one page\&q\&f=false) , acessado em 15 de maio de 2020 .

17 Este texto de Borges está disponível, na íntegra, no seguinte site acessado em 15 de maio de 2020 : (https://play.google.com/books/reader?id=0HZjAAAAcAAJ\&hl=pt\&pg=GBS.PR3). 
Cambio maritimo é um contracto d'emprestimo de dinheiro, ou cousa estimavel, no qual o emprestador, que toma o nome de Dador-a-risco estipula do mutuatario, que se denomina Tomador, um interesse como preşo dos perigos de mar de que se encarrega, e que se chama premio, acceita e adquire a bypotheca especial do objecto sobre que recahe o emprestimo, perde todo o direito á somma emprestada, perdido o objecto hypothecado no tempo e no logar dos riscos convencionados, tendo so direito á restituição do capital e cobrança do premio no caso do cumplemento feliz da especulação projectada (BORGES, 1830, Capítulo I, Parágrafo 1, p. 1-11). [...] A afinidade que o Cambio maritimo pode ter com outros contractos não tolhe que por si constitua uma especie distincta e particular de caracter aleatorio e condicional pelos riscos a que é sugeito, e pelo ponto a que é deferido o momento do ganho ou da perda. Os riscos são os do mar; e a condição consiste na chegada do navio a salvamento, ou das fazendas, de cuja verificação depende o cumplemento do contracto. Se a chegada é feliz, diz-se purificada a condição (BORGES, 1830, p. 11, grifo nosso).

Como se nota, o câmbio marítimo é visto por Borges como uma espécie distinta e particular de contrato de risco em relação a outros contratos, tais como os por ele denominados contratos de fazenda ou contratos de respondentia:

Os Francezes chamão ao Cambio-maritimo Contracto a grossa-aventura, por que o Dador expoem o seu dinheiro á aventura do mar, que importa risco ou perigo, e por que contribue na avaria grossa. Tãobem lhe chamão Contracto a torna-viajem - á retour de voyage, por que ordinariamento o Dador, que se torna então a commodo tanto de quem toma, como de quem presta o capital. Quando o dinheiro é dado sobre fazendas, o contracto chama-se de respondentia (BORGES, 1830, Capítulo I, parágrafo 1, Notas 7 e 8, p. 5-6). [...] Quando as fazendas obrigadas ao contracto sofrem deterioração, ou perda, meramente por defeito interno, ou diminuição no preço, o dono não se livra da responsabilidade contrahida pelo contracto abandonando: elle é adstricto ao inteiro pagamento da divida contrahida (BORGES, 1830, Capítulo VI, parágrafo 43, p. 100, itálicos nossos). [...] O artigo 326 do Codigo de Commercio de França diz: "Os decahimentos, diminuiçoens e perdas que acontecem pelo vicio proprio da cousa, e os damnos causados pelo facto do tomador não são a cargo do dador". A razão desta legislação è mui clara. Deterioração ou perda por vicio proprio da cousa não é damno acontecido por fortuna de mar ${ }^{18}$, por força maior, não é risco maritimo; e o dador não responde senão por estes, como temos repetidamente dicto. Diminuição de preço é igualmente um evento que não pode classificar-se em risco, e muito menos de mar, porque esse accidente da-se somente nos mercados. Em nenhum destes casos, pois, pode ter logar o abandono; e, ainda que o tomador o fizesse, não purgava a sua divida, - nem ele podia ser acceito $\mathrm{e}$ processado (BORGES, 1830, p. 100, grifo nosso).

Esta última observação de Borges nos fornece informações específicas acerca dos contratos de fazenda ou de respondentia, ao alertar-nos para o fato de que eles, embora também fossem classificados, tal como o contrato de câmbio marítimo, como contratos de risco aleatório, era preciso distingui-los entre si devido a dois aspectos diferenciais de caráter não aleatório que as práticas agrícolas não compartilhavam com as práticas náuticas da bodemeria, quais sejam, as deterioraçôes ou perdas por vício e os acidentes de mercado, de modo que tanto os descuidos e imperícia no trato das plantações ou a flutuação de preços das colheitas e da própria fazenda no mercado não

\footnotetext{
${ }_{18}$ Notemos que a palavra fortuna é aqui usada como sinônimo de acaso, isto é, como força difusa dotada do poder de influir quer no êxito quer no insucesso de pessoas ou de empreendimentos humanos.
} 
eram vistos como sinistros a serem cobertos pelos contratos de seguro de fazendas, de colheitas e de comercialização dos produtos agrícolas no mercado.

Percebe-se, assim, que, no campo de atividade jurídica português e francês do século 19, mesmo após o advento de teorias normativas de probabilidade no campo da matemática acadêmica francesa, os jogos referenciais on citacionais de linguagem ${ }^{19}$ - isto é, jogos que, na terminologia de Wittgenstein, poderiam ser nomeados jogos não efetivos de linguagem ${ }^{20}$ - que tomavam como objeto de normatização jurídica as práticas cujos propósitos eram vistos como condicionados por eventos aleatórios, pareciam ignorar completamente as potencialmente previsivieis contribuições que os produtores de tais teorias já previam, desde, pelo menos, o final do século 18. De fato, assim se expressava o matemático, astrônomo e físico francês PierreSimon Laplace (1749-1827), no primeiro parágrafo do seu livro Ensaio filosófico sobre as probabilidades:

Este Ensaio filosófico é o desenvolvimento de uma aula sobre as probabilidades que eu dei, em 1795, na École Normale, onde eu era professor, e que foi publicada no Jornal de Ciências daquela escola. Depois, eu também discuti esse mesmo tema em uma obra denominada Teoria analítica sobre as probabilidades. $\mathrm{Na}$ presente obra, eu exponho, sem recorrer à Análise, os princípios e resultados gerais dessa teoria; e os aplico a importantes questões da vida, que não são, com efeito, para a maior parte das pessoas, senão problemas de probabilidade. Mesmo considerando os princípios eternos da razão, da justiça e da humanidade, veremos que bá uma grande vantagem em seguir as probabilidades associadas a tais problemas, e graves inconvenientes em se descartá-las: estas probabilidades, como aqueles que se beneficiam das loterias, acabam sempre por prevalecer em meio às oscilaçôes do acaso (LAPLACE, 1814, p. 1, grifo nosso).

À primeira vista, poderia parecer razoável supor que a não referência a teorias de probabilidade por parte de jogos contratuais jurídico-normativos de linguagem relativos a práticas seguradoras diversas, cujos propósitos eram vistos como condicionados por eventos aleatórios - prática da bodemeria, práticas agrícolas, práticas de fazenda ou de respondentia, práticas de seguro de vida, dentre outras -, se devesse à não percepção, ou mesmo ao desconhecimento, de possíveis contribuições que tais teorias poderiam trazer quer para um controle normativo mais eficaz. e preciso de eventos casuais nos diferentes campos de atividade nos

\footnotetext{
${ }^{19}$ Estamos aqui usando a expressão jogos referenciais on citacionais de linguagem para nos referirmos, sobretudo, quer a jogos normativos de linguagem constituídos pelo discurso jurídico - que tomam como objeto de normatização ético-legal-estatal as relações interpessoais e aquelas que as pessoas estabelecem com outras instituições comunitárias, com o propósito de regular as condutas, deliberar sobre conflitos e transgressões de normas estabelecidas e prescrever penalidades - quer a jogos normativos de linguagem constituídos pelo discurso matemático, que tomam como objeto de normatização lógica as relações que humanos estabelecem entre si e/ou com os demais seres ou eventos naturais. É claro que jogos referenciais ou citacionais de linguagem não se restringem àqueles constituídos pelos discursos jurídicos ou matemáticos, mas envolvem também todos os jogos de linguagem que tematizam ou fazem referência direta ou indireta a outros jogos. Se, para nós, uma prática cultural é um modo efetivo de fazer, de agir com o corpo orientado pela gramática de um jogo de linguagem (andar de bicicleta, por exemplo), falar sobre uma prática cultural - por exemplo, sobre como se anda de bicicleta ou reportar-se verbalmente ou de outros modos a tal prática com qualquer propósito - constitui um jogo referencial ou citacional de linguagem.

${ }^{20}$ No parágrafo 124 das Investigaçoes filosóficas, Wittgenstein caracteriza, nos seguintes termos, o que ele denonima uso não efetivo da linguagem: "A filosofia não deve, de forma alguma, tocar o uso efetivo da linguagem; ela só pode, ao fim, descrevé-lo. Porque ela não pode tampouco fundamentá-lo. Ela deixa tudo como está. Ela deixa também a matemática como está, e nenhuma descoberta matemática pode fomentá-la" (WITTGENSTEIN, s/d, IF-124, p. 92). O uso que Wittgenstein faz, neste parágrafo, da expressão "usos não efetivos da linguagem" é o que chamamos, na nota anterior, jogos referenciais ou citacionais de linguagem. Assim, falar sobre um modo efetivo de fazer não é propriamente um fazer efetivo, do mesmo modo que, para Wittgenstein, pensar ou falar que se segue uma regra não é efetivamente segui-la. Não é nem propriamente agir em conformindade à regra e nem propriamente agir transgredindo-a. Pois, tanto para agir em conformidade quanto para agir para contrariá-la são formas efetivas de agir, isto é, formas efetivas de usar a linguagem.
} 
quais eles produziam efetivamente os seus sinistros, quer para a produção de legislação subsidiária à elaboração de contratos jurídico-normativos de risco que pudessem apaziguar de modo mais justo e menos polêmico os conflitos que poderiam se manifestar entre as partes em dissenso nesses contratos.

Esta suposição, pelo menos para o caso do elaboração de uma normatização jurídica adequada da prática de bodemeria, parece ter apoio no seguinte parecer jurídico manifesto por Borges, logo no prefácio da sua Synopsis Juridica do Contracto de Cambio Marítimo (BORGES, 1830):

A utilidade que aufere a sociedade convenção commercial conhecida com o nome juridico de cambio-maritimo vulgarmente entendido, na expressão geral, de dinheiro a risco, ou contracto de risco, é tão obvia e demonstrada oje, que seria pura ociosidade gastarmos tempo na sua exposição. [...] Sendo ha tanto tempo conbecido e praticado entre nós este contracto, parece que a sua legislação devia ter ja alcançado um grau tal-qual de certeza. Não acontece porem assim: o legislador não o entendeu até maio de 1810: as leis promulgadas té esta data são absurdas (BORGES, 1830, p. xiii, grifo nosso).

Assim, se por um lado a necessidade e a utilidade de tais contratos de risco se mostravam ao legislador mais do que evidentes e praxiologicamente comprovadas, por outro lado, ele não escondia o seu desconcerto diante da incompreensão e descompasso existentes entre a longevidade das regras situadas precisas que há muito vinham sendo verbalmente negociadas com o propósito de orientarem os jogos efetivos de linguagem condicionados por eventos considerados aleatórios em diferentes campos de atividade humana e a longevidade da imprecisão on inadequaşão das regras que, até então, vinham orientando a legislação subsidiária à elaboração de contratos jurídico-normativos de risco relativos a tais práticas. O que poderia explicar ou justificar a razão desse descompasso?

Talvez tenha sido essa preocupação manifesta já na Introdução da "Synopsis Juridica" e a necessidade correspondente de se extinguir tal descompasso que tenha levado o legislador a estabelecer, ao longo desse texto legal, inúmeras considerações comparativas entre diferentes modos de se normatizar juridicamente a prática da bodemeria que teriam vigorado entre povos de diferentes épocas e povos, sobretudo os romanos antigos. As seguintes considerações sugerem que a prática da bodemeria não era praticada do mesmo modo por comunidades náuticas de diferentes povos, de modo que as regras, os bens assegurados e os propósitos que orientavam os contratos jurídicos tinham as suas especificidades para cada caso particular:

Os Hollandezes chamão a esta estipulação Bomerie ou Bodemerije, palavra Flamenga que significa quilha esquipada. Esta especie de contracto Hollandes é um mutuo que, sob penhor do navio, o credor dá por um certo tempo, e até que este é a salvo; de baixo de condição de que sobre ganho diario se paguem pelos perigos, que se topem graves usuras; e que perecendo o navio, todo o capital emprestado pereça para o credor, a cujo risco somente navega a embarcação (BORGES, 1830, Capítulo I, parágrafo 1, Nota 9 , p. 7, itálicos nossos). [...] Os Ingležes dão a este contracto o nome de Bottomry; e por este entendem aquelle acto por que se hypotheca a favor do Dador do dinheiro o corpo do navio; de sorte que em caso de exito desventurado o Dador perde o seu dinheiro; e se o navio chega a salvamento, este, alem do seu dinheiro, retira um premio ou interesse convindo e correspondente ao risco. Se o interesse lhe é negado ou retardado tem acção real sobre o navio pelo pagamento. Na Inglaterra, como nos demais paizes, o contracto de Cambio maritimo praticou-se muito antes do que o de seguro. Quando os negociantes Inglezes 
querem fazer grandes especulaçoens, ou se achão por qualquer accidente em grande mingoa de dinheiro, fazem com o fornecedor um contracto de interesse-e-seguro sobre o navio pelo dinheiro tomado; e a hypotheca das fazendas carregadas se torna então a commodo tanto de quem toma, como de quem presta o capital [...] (BORGES, 1830, p. 6, grifo nosso)

A título de atestado da longevidade e das características particulares da prática de bodemeria, bem como de outras práticas protetoras contra riscos diversos em diferentes campos de atividade humana entre os povos antigos, algumas referências de Borges a essas práticas entre aos romanos merecem ser particularmente destacadas:

O nome de Cambio-maritimo ou nautico parece caber mais precipuamente ao espirito e qualidade do ganho nautico, a que os Romanos chamarão nauticum foenus ${ }^{21}$, e às causas por que os antigos o introduzirão no commercio, antes que fosse introduzido o uso dos seguros (BORGES, 1830, capítulo I, parágrafo 1, nota 17, p. 11). [...] Os antigos chamavão ao Cambio-maritimo ganho ou interesse nautico e quasi nada differia do dos nossos dias, pois que consistia então como oje n'aquellas usuras ou interesses que se devem pagar ao credor mutuante, que oje dizemos Dador a risco, pelo devedor mutuatario, que ora chamamos Tomador por se servir do dinheiro nos traficos maritimos, com a condição de que os riscos corressem por conta do Dador, e as vantagens a beneficio seu até um tanto por cento sobre o capital ministrado e arriscado. E faltando o corpo e objecto sobre que se dava a cambio, este se dissolvia, e se extinguia a hypotheca. Antes dos Imperadores Romanos não se acha exemplo deste interesse nautico; e no tempo de Claudio, Nero e Alexandre Severo acha-se delle menção. Nos tempos de Claudio, este principe, para remediar a publica miseria, resolveu-se a conceder todo o favor ao commercio maritimo e grandes interesses a quem o exercia: "Nam et negotiatoribus certa lucra propo suit suscepto in se damno, si cui quid per tempestates accidisse: et naves mercaturae, causa fabricantibus magna commoda" 22 . E tanto fizerão os principes de Roma para franquear os caminhos do commercio maritimo que, no tempo de Nero, ainda jovem, ouvido o Conselho do Senado, se pensou em moderar a sacca dos cereaes que se exportavão e os direitos que pagavão os navios mercantes. "Temperata apud transmarinas frumenti subvectio. Et ne censibus negotiatorum naves ascriberentur, tribu tumque pro illis perderent, constitutum" 23 . Segundo os antigos, o interesse nautico, tãobem chamado mutuo ou credito maritimo, era um contracto a perigo do credor que se podia fazer tanto com dinheiro como com as demais cousas consistentes em numero, pezo e medida. O dinheiro ou a cousa sobre que recahia o contracto para ser transportada por mar chamava-se dinheiro trajecticio ou nautico; e o perigo, escreve Modestino, começava a ser a cargo do credor no dia em que se convinha que o navio houvesse de navegar. (BORGES, 1830, capítulo I, parágrafo 1, notas 2 e 3, p. 3-4). [...] Entre os Romanos, se o navio obrigado ao interesse náutico perecia por caso fortuito, e sem culpa do devedor, a perda era a perigo do credor, desde o dia em que se tinha estabelecido que o navio navegasse ao lugar destinado. E sem uma convenção expressa, o caso de naufrágio era a risco do devedor" (BORGES, 1830, p. 92, grifo nosso).

Porém, em todo esse esforço comparativo empreendido pelo legislador ao longo da sua "Synopsis Juridica", não é perceptível qualquer indício de que ele tivesse ciência de que teorias de probabilidade poderiam, ainda que em parte, contribuir para que as práticas jurídicas relativas à elaboração de contratos de risco se adequassem com maior justiça e

\footnotetext{
${ }^{21}$ Interesse náutico. E aqui, a palavra interesse é sinônimo de juros cobrados sobre um capital investido num empreendimento de risco.

22 "De fato, propõe aos comerciantes um lucro certo, indenizando-os por qualquer perda que possa ter acontecido por tempestades no mar, e os navios de comércio devem receber grandes privilégios a quem os construiu".

23 "Para tornar o transporte transmarino de grãos menos oneroso, passou-se a regular tanto os cereais quanto os direitos que os navios mercantes pagavam".
} 
menor polêmica para um controle normativo dos eventos casuais nos diferentes campos de atividade nos quais eles produziam efetivamente os seus sinistros, sobretudo, no campo de atividade náutica no qual a prática de bodemeria havia sido e continuava sendo diversamente praticada.

Tornar-se, então, pertinente perguntar se os jogos referenciais de linguagem produzidos pelas teorias de probabilidade para se estabelecer um controle lógico-normativo genérico e abstrato sobre eventos aleatórios de qualquer natureza se prestariam, de fato, mesmo que apenas em parte, para a eliminação desse descompasso entre a diversidade de jogos de linguagem situados efetivamente produzidos em diferentes campos de atividade - e no interior de cada um desses campos - para se lidar com eventos aleatórios e os jogos referenciais de linguagem produzidos para se normatizá-los juridicamente.

\section{A contribuição das teorias de probabilidade para o aperfeiçoamento das práticas seguradoras}

As complicações dos contratos e a proliferação de legislações específicas sobre práticas de bodemeria e sobre outras práticas seguradoras de bens diversos contra riscos diversos, desde tempos remotos até os nossos dias, parecem, à primeira vista, depor contrariamente ou, pelo menos, relativizar o suposto poder lógico-normativo contributivo das teorias de probabilidade para o controle de eventos aleatórios nos diferentes campos de atividade humana nos quais eles se manifestam e para a efetividade do controle jurídiconormativo dos conflitos que podem se manifestar entre as partes envolvidas em práticas seguradoras de bens diversos contra riscos diversos. Passemos, então, a avaliar com mais cuidado esta hipótese.

Após a queda do Império Romano ocidental, orientado pelo propósito de unificar e expandir o Império Bizantino - o Império Romano oriental - e de criar uma legislação que fosse capaz de dar conta das demandas e litígios judiciais de sua época, o imperador bizantino Justiniano I constituiu uma comissão composta de destacados juristas que, com base na compilação de diversas constituições imperiais vigentes na época, elaboraram o que se denominou Suma Completa do Direito Romano (Corpus Juris Civilis ou Corpus Iuris Civilis Romanii), publicada em 1583 por Dionísio Godofredo (GODOFREDO, 1583). A imagem seguinte é a capa da primeira edição da Suma ${ }^{24}$ :

\footnotetext{
${ }^{24}$ Imagem extraída do site (https://pt.wikipedia.org/wiki/Corpus_Juris_Civilis), acessado em 20 de maio de 2020.
} 


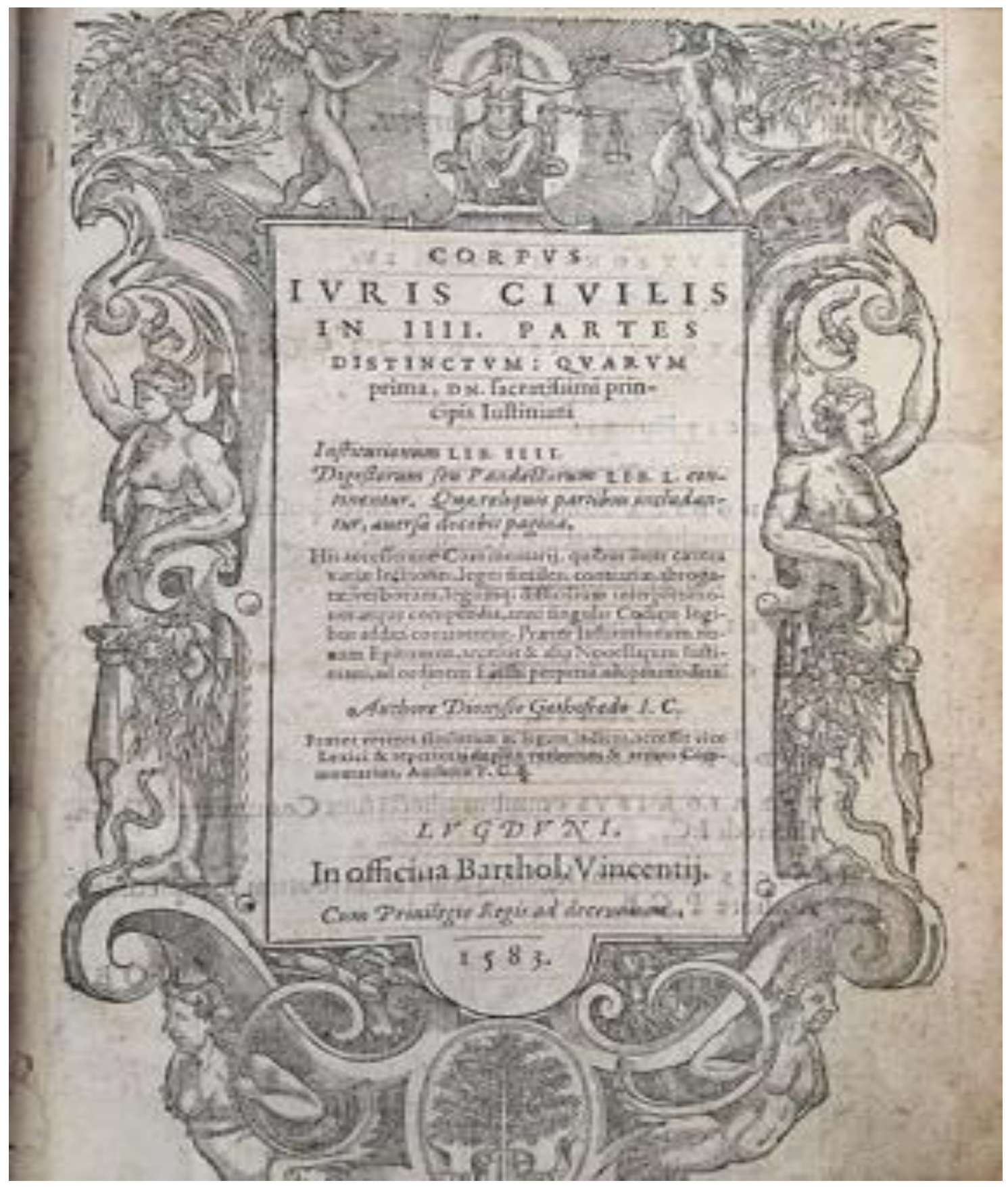

Nesta Suma, pode-se acusar rastros de estudos acerca de registros de nascimentos e mortes de pessoas para efeito de recebimento de anuidades por parte de seus familiares - que haviam sido anteriormente realizados pelo jurista romano Eneu Domício Ulpiano (150-223 a.C) - que sugerem que práticas de seguros de vida - análogas às que se realizam na atualidade eram realizadas em diferentes campos de atividade humana. A tabela seguinte (HALD, 2003, p. 117), denominada Tabela de Conversão de Ulpiano, mostra a duração do recebimento de anuidades por parte de familiares de pessoas asseguradas em função da faixa etária em que as suas mortes viessem a ocorrer. 


\section{Ulpian's Conversion Table}

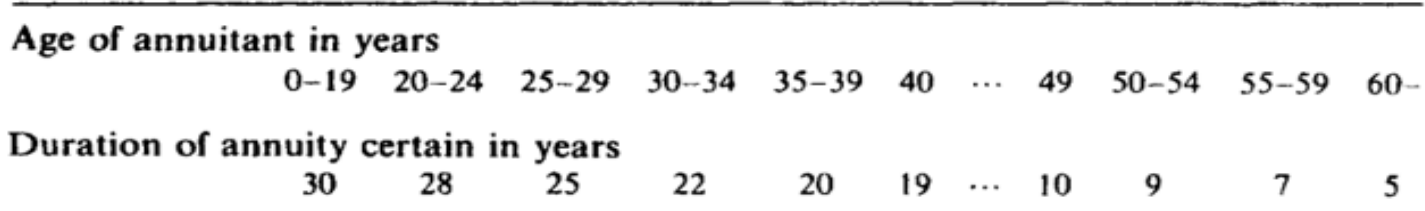

Tabela de Conversão de Ulpiano. Fonte: (HALD, 2003, p. 117)

Tal tabela - e tábuas semelhantes produzidas antes dela que poderiam ter inspirado a sua produção - parece ter sido usada, no campo jurídico do Império Romano, para a avaliação estatal de pedidos de auxílios para a subsistência, usufrutos ${ }^{25}$ e rendas vitalícias ${ }^{26}$, em espécie ou em dinheiro, a partir da aprovação da denominada Lei Falcidiana ${ }^{27}$, no ano 40 a.C. Essa lei, que permaneceu em vigor até o século VI d.C, dispunha sobre a divisão de heranças e determinava que um herdeiro (ou herdeiros) de uma propriedade nomeado(s) em testamento não deveria $(\mathrm{m})$ receber menos do que um quarto da propriedade deixada de herança e que não poderiam ser deixados como herança mais do que três quartos da propriedade. Caso o herdeiro recebesse mais do que três quartos da propriedade, haveria uma redução proporcional. A mesma situação acontecia para heranças de renda vitalícia, para as quais a tabela era mais utilizada (HALD, 2003, p. 116-117).

Como mostra a tabela de conversão de Ulpiano, quanto maioré a faixa etária - distribuídas em faixas etárias de cinco em cinco anos, a partir da primeira faixa que inclui pessoas com até 19 anos - em que ocorre a morte de uma pessoa, menoré a duração do recebimento de anuidades por parte de seus familiares, duração esta que decresce de 1 em 1, de 2 em 2 ou de 3 em 3 anos, até atingir o limite de 5 anos para os casos de mortes a partir dos 60 anos de idade. Assim, as durações dos recebimentos de anuidades por morte pelos familiares da vítima variam de modo inverso - mas não de modo proporcionalmente inverso - às faixas etárias de ocorrências dos sinistros, o que põe em evidência o critério ético-jurídico no qual se assentava a proposta de seguro de vida de Ulpiano presente no Corpus Juris Civilis, qual seja, quanto mais jovem viesse a falecer uma pessoa, maior era o tempo de recebimento de anuidades por parte de seus familiares.

As aplicações dessa tabela foram discutidas por Nicolas Bernoullii' ${ }^{28}$ (1687-1759), em 1709, pensando nos números como expectativas ou esperanças de vida. Durante a Idade Média, a venda de anuidades se tornou comum para que reinos e cidades arrecadassem antecipadamente fundos que pudessem reembolsar, no futuro, os familiares dos mortos que haviam contratado essa espécie de seguro previdenciário de vida. Contudo, esses contratos não levavam em consideração, para o cálculo dos valores das anuidades a serem futuramente recebidas pelos familiares a partir da ocorrência do sinistro, a idade do adquirente desse tipo de contrato previdenciário no ato de sua contratação.

\footnotetext{
${ }^{25}$ Direito conferido a alguém, durante certo tempo, de gozar ou fruir de um bem cuja propriedade pertence a outrem.

${ }^{26}$ Renda vitalícia é uma anuidade, ou uma renda estipulada que é recebida em intervalos fixos - e enquanto estiverem vivas - pelas pessoas que realizaram algum tipo de contrato vendido por empresas de seguro de vida.

${ }_{27}$ Publius Falcidius foi um antigo tribuno romano das gens falcidia - isto é, pertencente a uma família romana plebeia - que viveu por volta do século I a. C. e que teve uma atuação destacada no campo de atividade jurídica na Roma antiga. Daí, a Lei Falcidiana sobre disposição testamentária que leva o seu nome.

${ }^{28}$ Matemático suíço que fez o seu doutorado na Universidade da Basiléia, na Suíça, com uma dissertação sobre aplicações da teoria das probabilidades.
} 
Nicolas Bernoulli, Johan de Witt ${ }^{29}$ (1625-1672) e Edmond Halley ${ }^{30}$ (1656-1742) foram os precursores da ideia de se estabelecer uma relação de dependência entre as anuidades a serem recebidas e as idades e saúde dos indivíduos no ato de contratação do seguro.

Segundo Hald (2003), na França, em 1653, o banqueiro napolitano Lorenzo Tonti (1630-1695) propôs ao cardeal Mazarin a criação de um fundo de captação de recursos públicos através de vendas, por parte dos Estados monárquicos, de seguros previdenciários ou seguros de vida denominados tontinas:

As Tontinas tinham por objetivo inicial facilitar ao Estado o levantamento de empréstimos públicos. [...] a operacionalidade de tais instituições estava baseada no princípio de reunião de pessoas que colocavam em comum certa quantia em dinheiro, para constituir um fundo destinado a ser repartido em determinada época entre os sobreviventes do grupo" (GUIMARÃES, 2004, p. 7).

Guimarães (2004) e Cavicchini (2008) observam a ligação entre as Tontinas e os seguros de vida e destacam o fato de que essa prática foi acompanhada de atividades imorais, como fraudes, sequestros e assassinatos para se aumentar o valor das anuidades a serem recebidas. Tais atividades colocavam em descrédito o poder público e as autoridades constituídas, sobretudo quando se toma como termo de comparação a organização econômica e ética exemplar das guildas que, por desenvolverem práticas seguradoras autônomas e independentes dos poderes públicos constituídos, passaram a ser vistas como instituições concorrentes às estatais, sofrendo constantes ameaças e medidas repressivas por tais poderes, como assinala Le Goff:

Os elementos fundamentais da constituição de uma guilda são o juramento e a refeição. O juramento mútuo é um ato jurídico constitutivo e obrigatório. A refeição tem por função renovar permanentemente a associação juramentada. O juramento instaura a igualdade (a paridade) entre os membros da guilda e constitui um domínio jurídico próprio, por meio da adoção de estatutos. [...] As fontes medievais descrevem esse direito falando de voluntas ("vontade") e consuetudo ("costume"). Essa forma de direito tem por corolário uma jurisdição interna à guilda, que assegura a arbitragem das querelas e a manutenção da paz entre seus membros. Além disso, as guildas têm o direito de se autoadministrar e de eleger seus presidentes bem como os membros de seu tribunal. As associações juramentadas exercem efeitos pacificadores em seu próprio seio e no resto da sociedade. No começo da Idade Média, houve casos em que as guildas pegaram em armas para defender sua ordem jurídica própria ou para ajudar alguns de seus membros em disputas com terceiros. A refeição coletiva estava ligada ao ofício divino, às obras de caridade e à comemoração dos mortos, e, dessa forma, à rememoração de sua própria história. [...] Assim, a guilda constituía tanto uma ordem jurídica e uma ordem de paz nascidas de uma "conjuração", quanto um grupo religioso. Esses traços só poderiam fazer dela o alvo das autoridades estatais e eclesiásticas, a cujos ataques juntaram-se posteriormente as autoridades municipais. As disputas das guildas com as autoridades, que não hesitaram em empregar a difamação seguida muitas vezes de uma pura e simples proibição, foram durante séculos um elemento importante de sua história no Ocidente medieval (LE GOFF, 2017, p. 548-549).

\footnotetext{
${ }^{29}$ Jurista, matemático e político holandês, graduado em Direito e Matemática pela Universidade de Leiden, a mais antiga universidade dos Países Baixos.

30 Astrônomo e matemático britânico que previu que, em 1758, o cometa posteriormente denominado Halley, em sua homenagem, cruzaria o sistema solar.
} 
Por sua vez, devido à incapacidade da legislação de apaziguar os conflitos entre adquirentes dos seguros públicos e o poder público, foram desenvolvidas tabelas de mortalidade para a precificação das tontinas, porém, não tão detalhadas como as que já haviam sido desenvolvidas por John Graunt (1620-1674).

Comerciante e cientista britânico que, com base na coleta e estudos analíticos de dados sobre mortes ocorridas em Londres ao longo de um período de tempo, deu início à construção das primeiras tábuas de mortalidade. Com base nesses estudos, Graunt publicou, em 1662, a obra intitulada Natural and Political Observations upon the Bills of Mortality que serviu de base para o surgimento da demografia moderna e para o surgimento de um campo de estudos que, no século 18, foi denominado Aritmética Política e, no século 19, passou a ser chamado de Estatística.

Graunt foi responsável por tabelar vários dados sobre a população de Londres. Com em análises detalhadas desses dados, ele sugeriu a existência de vários eventos aleatórios que, na época, poderiam estar influenciando a dinâmica populacional, dentre os quais destacou as pestes, a relação entre o número de mulheres e o de homens numa determinada comunidade, a distribuição do número de pessoas de uma determinada cidade entre diferentes faixas etárias etc. As tabelas de mortalidade de Graunt inspiraram estudiosos e autoridades de várias outras cidades a montarem tabelas, como foi o caso de Paris, em 1667, e se tornaram também ferramentas básicas para estudos estatísticos médicos, estudos demográficos e para a posterior constituição da denominada ciência atuarial.

Por sua vez, uma análise probabilística de tábuas de mortalidade com o propósito de se calcular as anuidades a serem recebidas por contratantes de seguros de vida foi feita pelos irmãos Huygens, na Holanda, bem como por Halley, na Inglaterra. A fim de lidarem com questões relativas à expectativa ou esperança de vida de uma criança ou à definição de valores de anuidades, os irmãos Huygens estabeleceram uma analogia entre as tabelas de mortalidade e os jogos de azar e, com base nela, tomaram de empréstimo a linguagem utilizada nesses jogos para o tratamento estatístico dos dados dessas tabelas. Os estudos que eles realizaram foram de extrema importância para o cálculo dos valores de anuidades, pois faziam previsões do tempo durante o qual os cidadãos deveriam pagar os tributos estatais, de modo que nem cidadãos e nem Estado se sentissem em desvantagem ou fraudados uns em relação ao outro, evitando-se, portanto, os litígios judiciais em relação a práticas seguradoras contra riscos diversos.

Abraham de Moivre ${ }^{31}$ deu continuidade aos estudos de Halley e publicou o seu trabalho, em 1725, no livro intitulado "Annuities upon Lives: or, The V aluation of Annuities upon any Number of Lives; as also of Reversions. To which is added, $\mathrm{Na}$ Appendix concerning the Expectations of Life, and Probabilities of Survivorship" ${ }^{32}$. Como se observa já pelo título do estudo, o campo de seguros de vida passa a ser visto por De Moivre como uma aplicaşão das teorias de probabilidade.

Seguindo esta mesma orientação, no final do século 19, o matemático francês Henri Poincaré (1854-1912), referindo-se explicitamente àquilo que ele entende ser uma aplicaşão do cálculo de probabilidades ao campo atuarial de atividade humana, assim se expressou em

\footnotetext{
31 Matemático francês que se notabilizou pela invenção do modo de se traduzir a escrita de um número para a linguagem trigonométrica, bem como por seus estudos sobre probabilidades e sobre a distribuição normal de eventos aleatórios.

32 "Anuidades por vidas: ou, A avaliação de anuidades para um número qualquer de vidas; como também de reversões. À qual se acrescenta o Anexo sobre as expectativas de vida e sobre as probabilidades de sobrevivência”.
} 
relação à contribuição - mais em benefício das companhias seguradoras do que nos de seus assegurados - de teorias de probabilidade a práticas de seguro de vida:

O diretor de uma compania de seguros de vida ignora quando morrerá cada um de seus assegurados, mas se baseia no cálculo de probabilidades e na lei dos grandes números, e não se equivoca, posto que distribui dividendos a seus acionistas. Estes dividendos não se evaporariam se, uma vez subscritas as apólices, um médico extremamente perspicaz e indiscreto investigasse e informasse o diretor sobre as mortes de seus assegurados. Este médico dissiparia a ignorância do diretor, mas não influiria sobre os dividendos que, evidentemente, não são um produto desta ignorância (POINCARÉ, 1968, p. 69).

De acordo com Miguel (2020, p. 36),

[...] o que Poincaré está dizendo com isso é análogo a se dizer que após o lance de um dado cúbico, uma única vez, é absolutamente imprevisivel que, após a sua queda, a face voltada para cima mostre o número 1 ou 2 ou 3 ou 4 ou 5 ou 6. Porém, ele parece estar supondo que a experiência prova (o que equivaleria, talvez, a dizer que o acaso prova?) que repetindo-se $n$ vezes o lançamento desse dado - $n$ tendendo ao infinito -, a ocorrência do fato 'a face do dado que se volta para cima é 1 ou 2 on 3 on 4 on 5 on 6 ' tende a estabilizar-se em torno de $1 / 6$ (um sexto), independentemente de realizarmos ou não essa experiência. Em outras palavras, Poincaré está significando a palavra probabilidade como a frequência-limite da repetição ad infinitum de um evento, como usualmente se faz no campo das ciências ditas experimentais como a Estatística, a Física, a Economia etc.

Na seção XXII das Observações filosóficas, Wittgenstein (2005) apresenta uma discussão que sugere um modo completamente inusitado de se falar em probabilidades em conexão a fenômenos considerados aleatórios, ao afirmar:

Qualquer expectativa "razoável" é uma expectativa de que uma regra que observamos até agora continuará a ser válida. Mas a regra tem de ter sido observada e não pode, ela também, ser somente esperada. A Teoria da Probabilidade só se interessa pelo estado da expectativa no sentido em que a lógica se interessa pelo pensamento. Em vez disso, a probabilidade diz respeito à forma e a um padrão de expectativa. É uma questão de esperar que a experiência futura obedeça a uma regra a que a experiência anterior obedeceu. "É provável que ocorra um dado evento" significa: algo fala em favor da ocorrência desse evento (WITTGENSTEIN, OF-237, p. 242-243, grifo nosso).

O que Wittgenstein parece estar querendo dizer com isso é que uma teoria formal, abstrata e genérica de probabilidade, como qualquer teorização acerca de um fenômeno que tenta acomodar todos os casos particulares em regras gerais supostamente válidas para todos os casos, não pode dar conta, por si só, de orientar as práticas específicas de se lidar com o problema do acaso, do modo como ele diversamente se manifesta em diferentes campos de atividade humana. Isso porque, as regras constituintes de critérios adequados para se lidar com cada problema específico em que o acaso intervém deverão não apenas ser esperadas, mas também e sobretudo, observadas através de estudos e registros específicos de ocorrências relativos ao evento aleatório sobre o qual se deseja estabelecer um controle considerado adequado. De fato, para ele,

[...] quando um jogador ou uma companhia de seguros são guiados pela probabilidade, eles não são guiados pelo cálculo de probabilidades, já que não podemos nos guiar somente por isso, visto que qualquer coisa que acontece pode ser relacionada com ela: não, a companhia de seguros é guiada por uma frequência efetivamente observada. E 
esta é naturalmente uma frequência absoluta (WIT"TGENSTEIN, OF-234, p. 241, grifo nosso).

Então, à luz desse modo wittgensteiniano de se conceber a insuficiência do cálculo de probabilidades para se inventar práticas adequadas para se lidar com problemas humanos em que o acaso intervém, seria possível dizer que a prática de seguro de vida proposta pela Tabela de Conversão de Ulpiano, embora não tivesse sido - e nem poderia ter sido - inventada com base em qualquer teoria ou cálculo de probabilidades inexistentes na época, estava baseada, porém, em estudos e registros anuais reiterados de diferentes frequências de mortes em diferentes faixas etárias na cidade em que o jurista viveu. Teriam sido nessas observações e registros anualmente reiterados que Ulpiano se baseou para produziu um critério considerado justo e legalmente adequado para elaborar uma tabela que pudesse orientar as diferentes associações de trabalhadores no ressarcimento anual considerado justo aos familiares da vítima cujo chefe de familia havia feito um investimento antecipado para assegurar as vidas de seus dependentes após a sua morte.

Esse modo wittgensteiniano de se conceber a insuficiência do cálculo de probabilidades para se inventar práticas adequadas para se lidar com problemas humanos em que o acaso intervém esclarece também em que sentido seria metodologicamente legítimo se afirmar, sob o ponto de vista de uma historiografia das práticas culturais de seguros de bens diversos contra riscos diversos, que não foi preciso esperar pelo advento de conceitos de probabilidade e de teorizações sobre o controle normativo de eventos considerados aleatórios para se lidar de modo, ainda que parcialmente satisfatório, com tais eventos.

E é nesse sentido que também se pode dizer que sem a invenção de práticas culturais de seguros de bens diversos contra riscos diversos em diferentes campos de atividade humana, nenhum conceito ou teorização sobre probabilidades que viriam, posteriormente, a fundar o campo disciplinar da Estatística poderiam ter sido produzidos. São as práticas que se inventam, em diferentes campos de atividade humana, para se lidar com determinados tipos de problemas que antecedem as suas teorizações e disciplinarização, e não o contrário.

Nesse sentido, o resultado geral para o qual esta nossa breve investigação aponta é que a emergência e o desenvolvimento de práticas seguradoras diversas, de teorias probabilidade como um campo particular e específico de investigação matemática, da Estatística como um campo autônomo de investigação de eventos aleatórios e da Ciência Atuarial como um campo autônomo recente de investigação de métodos e técnicas normativas específicas de análise e controle de riscos e, portanto, de produção, com base na estatística e na matemática financeira, de novas práticas seguradoras de bens diversos em diferentes campos de atividade humana e, sobretudo no campo da administração pública ou privada de seguros e fundos de pensão, constituem histórias diversas, que seguiram e continuam seguindo caminhos e perseguindo propósitos diversos. Histórias descontinuas e não evolutivas que, a partir de momentos diversos, procuraram estabelecer entre si diálogos diversos, apropriando-se, umas das outras, problemas, conceitos, técnicas, métodos procedimentais e métodos de validação diversos, adaptando-os em função da sua maior ou menor conveniência, precisão, poder preditivo ou eficácia para se lidar com problemas emergentes em seus próprios campos de atividade.

$\mathrm{Na}$ seção seguinte, a título de exemplo corroborativo do resultado a que conduziu este nosso estudo historiográfico, apresentamos um estudo de caso específico realizado em 2018, na cidade de Campinas (SP), acerca das regras integrantes da gramática que orienta o 
jogo de linguagem do cálculo do preço de um seguro de veículos automotivos que se realiza no campo atuarial de atividade humana.

\section{Um estudo de caso de uma prática seguradora de veículos automotivos no campo atuarial de atividade humana}

No campo de atividade do financiamento e comércio de apólices de seguros de bens móveis ou imóveis da atualidade, as diferentes práticas de precificação do risco para se definir um prêmio para os diferentes tipos de seguros são, em geral, realizadas a partir de uma análise estatística de sinistros passados, a fim de se projetar as probabilidades de ocorrência de sinistros futuros. Para definir melhor o risco, as seguradoras estabelecem um perfil para o cliente, traçado a partir de um questionário respondido pelo mesmo. Contudo, existem situações que não podem ser analisadas por estatísticas passadas - como é o caso de terremotos e furacões - devido à inexistência de registros suficientes para uma análise. Nesses casos, as seguradoras recorrem a métodos mais complexos para realizarem projeções futuras, como por exemplo, Modelos de Precificação de Ruinas. Procuramos aqui entender e descrever algumas das práticas normativas realizadas pelos sujeitos diretamente envolvidos com o campo de atividade seguradora na atualidade a fim de lidarem com o risco e a incerteza nos cálculos de seguros automotivos.

As análises e a precificação são feitas pelo atuário, isto é, por um profissional formado em "Ciência Atuaria". A palavra atuário vem do latim actuarǔus, a qual, originalmente, segundo o dicionário Michaelis, designava o "escriba cuja função era redigir as atas do senado romano". No Brasil, a profissionalização do atuário - juridicamente constituído como um profissional com formação específica e especializada em Ciência Atuária - foi regulamentada pelo Decreto ${ }^{\circ}$ 66.408 de 1970:

Art. $1^{\circ}$ Entende-se por atuário o técnico especializado em matemática superior que atua, de modo geral, no mercado econômico-financeiro, promovendo pesquisas e estabelecendo planos e políticas de investimentos e amortizações e, em seguro privado e social, calculando probabilidades de eventos, avaliando riscos e fixando prêmios, indenizações, benefícios e reservas matemáticas. (BRASIL, 1970).

Dentre as práticas a serem realizadas por um atuário, previstas no Capítulo III do Decreto no 66.408, destaca-se: "II - a determinação e a tarifação dos prêmios de seguros e dos prêmios de capitalização, bem como dos prêmios especiais ou extraprêmios relativos a riscos especiais" (BRASIL, 1970). Cabe, então, a esse profissional a tarifação dos prêmios de seguros.

Os cálculos a serem realizados pelos atuários para tarifação do seguro não obedecem a um conjunto de regras previamente estabelecidas e especificadas a serem seguidas objetivamente. As empresas seguradoras são livres para definirem os seus preços pelo método que acharem mais vantajoso para si. Entretanto, elas são obrigadas a elaborar um documento nomeado Nota Técnica Atuarial, assinada por um atuário responsável, que deve ser encaminhada à avaliação da SUSEP, que poderá ou não aprovar a comercialização do produto. Este documento:

[...] é um estudo matemático e atuarial, feito por técnico capacitado, que serve para fixar as taxas dos prêmios de seguro. Por exigência da Susep, as Notas Técnicas de prêmios 
deverão explicitar o prêmio puro, o carregamento, a taxa de juros, o fracionamento e todos os demais parâmetros concernentes à mensuração do risco e dos custos agregados, observando-se, em qualquer hipótese, a equivalência atuarial dos compromissos futuros (TSS, 2020).

O documento é sigiloso e os únicos que possuem acesso ao mesmo são os responsáveis da seguradora pelo documento e o órgão responsável pela regulamentação do seguro, no caso dos automotivos, a SUSEP ${ }^{33}$.

$\mathrm{Na}$ nota técnica também é colocado o cálculo de provisões técnicas. De maneira simples, a provisão técnica é a quantidade de capital que a seguradora deve reservar para que possa cobrir possíveis sinistros. Para seguros automotivos é comum ser utilizada a PSL - Provisões de Sinistros a Liquidar.

A PSL, especificamente, é a soma que a seguradora deve ter para cobrir os valores dos sinistros já avisados pelos segurados. Esses dados devem ser enviados à SUSEP mensalmente, a fim de verificar a consistência das informações de entrada e saída das provisões ${ }^{34}$.

Alguns exemplos de tarifação, ou seja, cálculo do preço de Seguros, são explorados por Paulo Pereira Ferreira, no livro Modelos de Precificação e Ruina para Seguros de Curto Prazo que, segundo o autor, foi a primeira literatura sobre Teoria do Risco escrita em língua portuguesa. Nele, o autor apresenta alguns métodos utilizados para efetuar os cálculos dos prêmios, o preço que será pago pelo seguro.

No processo de cálculo de um seguro existem três tipos de prêmios:

1. Prêmio de Risco;

2. Prêmio Puro;

3. Prêmio Comercial.

O Prêmio de Risco consiste em encontrar o valor total que a seguradora gastaria, considerando-se o valor médio de gasto com cada sinistro e a probabilidade de ocorrer um sinistro. O Prêmio Puro é o valor do prêmio de risco adicionado de um carregamento de segurança, uma margem para cobrir eventuais flutuações no comportamento do risco. Por fim, o Prêmio Comercial é aquele que será cobrado do cliente, que é o prêmio puro adicionado de um carregamento de despesas, para cobrir impostos, custo da apólice, gastos da empresa etc. Algumas referências ainda incluem uma quarta etapa, o prêmio bruto, separando as despesas administrativas no carregamento de despesas, e os impostos, custo de apólice, IOF e afins no prêmio bruto.

Para que valores sejam calculados, existem métodos de tarifação que variam de acordo com o tipo de risco a ser segurado. Alguns deles são apresentados por Ferreira (2010).

\footnotetext{
33 SUSEP é a sigla de "Superintendência de Seguros Privados", cujo site é o seguinte: (http://novosite.susep.gov.br).

34 Mais informações estão disponíveis nas "Orientações da SUSEP ao Mercado" no seguinte site, http://www.susep.gov.br/setores-susep/cgsoa/copra/arquivos-

copra/orientacoes/Orientacoes $\% 20$ sobre $\% 20$ Provisoes $\% 20$ Tecnicas $\% 20-020$ Versao $\% 20-02002 \% 20-02002 \% 20$ $\% 202015$.pdf). acessado em 20 maio 2020:
} 


\section{Tarifação Subjetiva}

Costuma-se utilizar esse método quando não é possível obter dados suficientes para um trabalho estatístico sobre os sinistros. A tarifa, nesse caso, é definida pelo segurador (underwirter) por meio de comparações com riscos similares. Pode-se também incluir a Teoria da Credibilidade que consiste em atualizar sistematicamente as tarifas dos seguros de acordo com a disponibilização da experiência de sinistros:

A Teoria da Credibilidade se torna mais importante quando o volume de informações é muito pequeno, conduzindo a uma instabilidade muito grande na estimativa do preço do seguro. A solução defendida pela Teoria da Credibilidade é a utilização de experiência de riscos similares ou de riscos idênticos referentes a experiências de períodos anteriores, experiências essas conjugadas com a experiência mais recente do risco a ser precificado. É possível utilizar-se, no rol de riscos similares, da experiência de outras seguradoras ou, então, do mercado segurador (FERREIRA, 2010).

\section{Sinistralidade}

Denomina-se sinistralidade a razão entre o Prêmio de Risco e o Prêmio Comercial:

$$
\text { Sinistralidade }=\frac{\text { Prêmio de Risco }}{\text { Prếmio Comercial }}
$$

Esse índice determina a razão entre os gastos de uma empresa e a sua renda. Caso a sinistralidade de um plano tenha sido baixa, ou seja, tenha sido gasto pouco com indenizações e a renda tenha sido alta, é possível que se diminua o preço dos próximos contratos. Esse método considera os gastos anteriores, mas é preciso cautela, pois qualquer alteração na forma como é calculado o prêmio de risco ou comercial altera a forma como se calcula a sinistralidade.

\section{Prêmio Puro}

Inicia-se o processo com uma estimativa para o Prêmio de Risco, passando por um processo de regularização estatística, um processo de modelagem estatística, visando ajustar a estimativa às estatísticas e adiciona-se o carregamento de segurança.

\section{Tábuas de Mortalidade}

As tábuas de mortalidade são usadas em seguros de vida. Essas tábuas nada mais são do que dados estatísticos que preveem a expectativa de vida da população, de acordo com as características procuradas.

Esses métodos são, de maneira geral, responsáveis por definirem como a tarifa a ser paga pelo segurado será obtida. Ainda é necessário que se faça o cálculo dessas tarifas. Alguns princípios para realização deste cálculo são também apresentados por Ferreira (2010).

O princípio de cálculo de prêmio é uma função que associa a cada distribuição de sinistros $S$ um número real $P$. $S$ é uma variável aleatória que representa a distribuição de 
sinistros, obtida a partir de alguma modelagem estatística. Essa modelagem é uma das informações que devem estar na Nota Técnica Atuarial, definida pela seguradora.

A função princípio de cálculo é chamada de "função de distribuição acumulada de $S$ no ponto $x$ " ou "função densidade de probabilidade". De maneira simples, o segurador recebe um valor $P$ fixo e gasta um valor $S$ indenizando sinistros.

\section{Princípio de Equivalência}

$$
P=E[S]=\text { Prềnio de Risco }
$$

O valor $P$ é definido, neste princípio, como a esperança de $S$, ou média de $S$. Trabalhando-se com um número $n$ de anos, o segurador terá a distribuição de sinistros agregada de cada ano e, em média:

$$
\lim _{n \rightarrow \infty} \frac{S_{1}+S_{2}+S_{3}+\cdots+S_{i}}{n}=E[S]
$$

Nessa base de operação, temos a garantia de que o segurador se arruinará. Isso decorre de um teorema existente na teoria dos jogos: "[...] se a banca (seguradora) jogar contra um jogador (segurado) infinitamente mais rico (pois o fluxo de novos prêmios ao longo do tempo é inesgotável), com as mesmas chances $(P=E[S])$, então, ao longo do tempo, certamente a banca se arruinará" (FERREIRA, 2010, p. 8).

\section{Princípio do Valor Esperado}

$$
P=E[S]+\theta \cdot E[S]=E[S] \cdot(1+\theta)
$$

Nesse princípio, calcula-se inicialmente o Prêmio Puro $(P)$ e adiciona-se o carregamento de segurança $\theta$, normalmente entre $5 \%$ e $10 \%$, variando de acordo com o grau de aversão ao risco da seguradora. A diferença desse para o princípio anterior é o carregamento de segurança, garantindo fundos para eventuais flutuações sobre o risco.

\section{Princípio da Variância}

$$
P=E[S]+\alpha \cdot \operatorname{Var}[S]
$$

Utiliza-se, nesse princípio, a variância de $S$. A variância mostra quão distante os valores estão da média. O fator $\alpha$ é escolhido arbitrariamente, o que dificulta a utilização desse princípio, uma vez que a variância e a esperança possuem ordens de grandeza diferentes, não sendo muito utilizado na prática.

\section{Princípio do Desvio Padrão}

$$
P=E[S]+\beta \cdot \sigma(S)
$$


Assim como o fator $\alpha$ do Princípio da Variância, o fator $\beta$ é escolhido arbitrariamente, entre 1 e 2 , e $\sigma(\mathrm{s})$ é o desvio padrão dos valores.

\section{Princípio de Utilidade Zero}

Nesse princípio, utiliza-se um conceito existente na Teoria do Consumidor, área trabalhada na Economia, que é a Função Utilidade. Essa função regula a preferência pessoal de cada cliente sobre determinado produto, definindo-se utilidade como a satisfação ou benefício ao adquirir a mercadoria.

No mercado de seguros, podemos definir uma função utilidade para o cliente e para a seguradora. Conseguimos identificar facilmente algumas informações sobre a função:

- $\quad$ A função associa a cada excedente $x$ em relação à riqueza inicial $W$ um valor $\mu(\mathrm{x})$;

- Quanto mais gastos o produto gerar, menor será a satisfação, tanto do segurador quanto do segurado, $\log , \mu^{\prime}(x)>0$, ou seja, a função deve ser crescente;

- Novamente, quanto maior os gastos, menor a satisfação, portanto, $\mu^{\prime \prime}(x)>0$, que representa a diminuição da taxa crescimento com o aumento da variável $x$.

O objetivo de se formular uma função com essas características é calcular um preço para o seguro que seja satisfatório para o segurador e o segurado. Esse princípio é pouco utilizado na prática por necessitar de uma formulação para cada cliente, tornando-se inviável para seguros muito contratados, como o automotivo.

\section{Princípio Percentil}

$$
F_{S}(P)=P(S \leq P)=1-\alpha
$$

Trata-se de definir o prêmio considerando-se uma probabilidade pequena $(\alpha)$ do montante de sinistros $(\mathrm{S})$ superar o prêmio puro (P). O valor de $\alpha$ é escolhido arbitrariamente, costumando-se manter entre $1 \%$ e $10 \%$.

Esses são alguns princípios que podem ser utilizados para o cálculo dos prêmios para tarifação dos seguros. Na prática, os mais utilizados são o princípio do valor esperado, do desvio padrão e o percentil.

Observamos também que são muito utilizados os conceitos estatísticos de variância e de desvio padrão, bem como conceitos de teoria de probabilidades, como o de esperança, além de conceitos econômicos, como o de função utilidade, que não utilizam a noção de probabilidade como ferramenta fundamental para o cálculo. Ressaltamos, também, que esses princípios são utilizados em cálculos atuariais. Ainda é necessário, em cada um deles, modelar o problema estatisticamente. As informações sobre cálculos apresentadas foram obtidas no livro de Ferreira e no site Tudo Sobre Seguros ${ }^{35}$, organizado pela ENS - Escola Nacional de Seguros.

No âmbito acadêmico, existem pesquisas que visam entender a influência de certos fatores no preço final do contrato. Wélison Alves Neto, em seu trabalho de conclusão de

\footnotetext{
35 Disponível em: <https://www.tudosobreseguros.org.br/saiba-tudo-sobre-calculo-de-premios-em-seguros/>. Acesso em: 06 ago. 2020.
} 
curso, utiliza um método conhecido como "Método dos Prȩcos Hedônicos" para entender a formação dos preços de apólices. Esse método consiste em quantificar fatores subjetivos, como a satisfação ou a utilidade proporcionada ao consumidor, para entender como eles influenciam no preço final do produto. A teoria que sustenta tal método foi proposta em 1928, por F. V. Waugh. Tal teoria foi proposta com base em informações provenientes do comércio de tomates, aspargos e pepinos, que constataram que algumas características físicas dos produtos aumentavam as vendas. O método dos prẹcos hedônicos foi inicialmente aplicado no setor agrícola. Atualmente, se aplica a diversos campos de atividade humana, tais como o automobilístico, o agrícola e do mercado de eletrônicos.

$\mathrm{Na}$ pesquisa, foram utilizados dados cedidos por uma seguradora da cidade de Vinhedo (SP) e consideramos algumas características como variáveis: o modelo do carro, o ano de fabricação, a presença de dispositivo antifurto, o gênero do motorista, a faixa etária do condutor e a seguradora responsável pelo contrato. Para análise dos dados, o autor utiliza um modelo logarítmico para modelar o preço do seguro. Com o modelo, procurou-se a variação do preço em função de uma característica e sem ela, de forma a verificar a influência de cada variável sobre valor final. Alguns resultados da análise foram:

- Modelo: modelos mais potentes ou com maior índice de roubos historicamente apresentam maior risco, portanto, mais caro o seguro.

- Idade do condutor: constatou-se que condutores entre 18 e 24 anos representam um acréscimo no preço da apólice, uma vez que, saindo mais no período noturno, os jovens se expõem a mais riscos.

- Ano do veículo: modelos mais antigos encarecem o preço das apólices, uma vez que o mercado de peças é mais restrito, pois as montadoras podem deixar de fabricá-las em um período de dez anos após o lançamento do veículo.

- Seguradora: os preços variam dentre as seguradoras de acordo com a forma de cálculo utilizado por elas para definição das tarifas.

- Gênero do condutor: condutores do gênero masculino costumam pagar mais caro pelo seguro. Observa-se que isso acontece, uma vez que um quinto dos condutores internados no SUS por acidentes de transito são homens ${ }^{36}$.

- Dispositivo antifurto: a presença do dispositivo pode acarretar um desconto no preço da apólice, uma vez que reduz o risco que a seguradora assume.

Esses dados mostram, por características isoladas, qual a importância do perfil do segurado para a seguradora. A definição do perfil garante à seguradora ter uma precisão de quais riscos ela assumirá com o contrato.

O universo de trabalhos na área de precificação de seguros é amplo e diversificado. Cada ramo de seguro apresenta diferentes tipos de tarifação e métodos de precificação. Além disso, os dados estatísticos utilizados por cada seguradora podem variar, dependendo da sua localidade. Por isso, a necessidade de se trabalhar com uma modelagem estatística bem definida. O sigilo imposto nesses cálculos pelas seguradoras ocorrem para que não ocorra "plágio" das análises estatísticas realizadas.

\footnotetext{
${ }^{36}$ Dados recolhidos no ano de 2012.
} 


\section{Referências}

ALVES NETO, Welison. Análise de fatores que influenciam o Preço de Apólices de Seguros de Automóveis: evidências para a região de Vinhedo. 2016. 54 f. Monografia (Especialização em Economia) - Instituto de Economia da Universidade Estadual de Campinas, Campinas, 2016. Disponível em:

$<$ http://www.bibliotecadigital.unicamp.br/document/?down=000984809>. Acesso em 13 ago. 2020

BERNSTEIN, Peter L. Desafio aos Deuses. Tradução de I. Korytowski. Rio de Janeiro: Elsevier, 2011.

BORGES, José F. Synopsis Juridica do Contracto de Cambio Marítimo vulgarmente denominado Contrato de Risco. Londres: Bingham, 1830.

BOYER, Carl. B. História da Matemática. Tradução Elza F. Gomide. São Paulo: Editora da Universidade de São Paulo, 1974.

BRASIL. Decreto-Lei no 66.408, de 3 de abril de 1970. Dispõe sobre a regulamentação do exercício da profissão de Atuário, de acordo com o Decreto-lei no 806, de 4 de setembro de 1969. Disponível em: < http://www.planalto.gov.br/ccivil_03/decreto/19701979/d66408.htm> . Acesso em: ago. 2020.

CAVICCHINI, Alexis. A História dos Seguros no Brasil. Rio de Janeiro: RJ Cop Editora, 2008.

FERREIRA, Paulo P. Modelos de precificação e ruína para seguros de curto prazo. Rio de Janeiro: FUNENSEG, 2010.

GODOFREDO, Dionísio. Suma Completa do Direito Romano (Corpus Juris Civilis ou Corpus Iuris Civilis Romanii), 1583.

GUIMARÃES, Sérgio R. Fundamentação Atuarial dos seguros de vida: um estudo comparativo entre os seguros de vida individual e em grupo. Série de Cadernos de Seguro: teses, v. 9, no 20. FUNENSEG, Rio de Janeiro, 2004.

HAMURABI, Código. Disponível em: < $\underline{\text { https://www.portalsaofrancisco.com.br/historia- }}$ geral/codigo-de-hamurabi),c.1800 a.C >.

Acesso em julho de 2020

HALD, Anders. A History of Probability and Statistics and their Applications before 1750. John Wiley \& Sons, 2003.

HAMBURGENSIS, Henricus R. Bodemeria. Dissertação acadêmica. Faculdade Jurídica. Brandemburgo, 1697. 
IFRAH, Georges. Os números: a história de uma grande invenção. Trad. Stella Maria de Freitas Senra. Rio de Janeiro: Globo, 1989.

LAPLACE, Pierre-Simon. Philosophical Essay on the Probabilities. Paris: $\mathrm{M}^{\mathrm{ME}} \mathrm{V}^{\mathrm{X}}$ Courcier Imprimeur-Libraire pour les Mathématiques, 1814.

LE GOFF, Jaques.; SCHMITT, Jean-Claude. (Orgs.). Dicionário analítico do Ocidente medieval. Tradução coordenada por Hilário Franco Júnior. São Paulo: Editora Unesp, 2017.

MIGUEL, Antonio. Art Requiem: um anti-poema dada digital para o ocaso da arte casual. Revista Internacional de Pesquisa em Educação Matemática, Porto Alegre (RS), v. 10, n. 2, p. 14-57, junho de 2020.

POINCARÉ, Henri. El azar. In: NEWMAN R. J. El mundo de las matematicas.

Traduccion: César Villazón. Barcelona: Ediciones Grijalbo, 1968. p. 68-82.

PONCE, Aníbal. Educação e luta de classes. 4. ed. Tradução de José Severo de Camargo Pereira. São Paulo: Cortez, 1983.

SIMÕES DE PAULA, Eurípedes. Hamurabi e o seu código. Revista de História, São Paulo, Ano XIV, v. XXVII, n. 56, p. 257-270, out./dez. 1963.

TSS. Nota Técnica Atuarial. Verbete acessível no Glossário do site "Tudo Sobre Seguros" (TSS) Disponível em: < https://www.tudosobreseguros.org.br/glossario/>. Acesso em 15 de agosto de 2020.

WITTGENSTEIN, Ludwig. Investigações filosóficas/Philosophische untersuchungen. Edição bilingue alemão/português. Apresentação, Tradução e Notas de João José R. L. de Almeida. Wittgenstein Translations, s/d. Disponível em: < http://www.psicanaliseefilosofia.com.br/textos/InvestigacoesFilosoficas-Original.pdf $>$. Acesso em 12 ago 2020.

Observações filosóficas. Tradução Adail Sobral e Maia Stela Gonçalves. São Paulo: Edições Loyola, 2005. 